\title{
Wild-type p53 transgenic mice exhibit altered differentiation of the ureteric bud and possess small kidneys
}

\author{
Lucy A. Godley, ${ }^{1}$ Jeffrey B. Kopp, ${ }^{2}$ Michael Eckhaus, ${ }^{3}$ Jennifer J. Paglino, ${ }^{2}$ Jennie Owens, ${ }^{3}$ \\ and Harold E. Varmus ${ }^{1,4,5}$ \\ ${ }^{1}$ Varmus Laboratory, National Cancer Institute, National Institutes of Health (NIH) Bethesda, Maryland 20892 USA and \\ Department of Biochemistry and Biophysics, University of California, San Francisco, California, 94143 USA; ${ }^{2} \mathrm{Kidney}$ \\ Disease Section, Metabolic Diseases Branch, National Institute of Diabetes and Digestive and Kidney Diseases, NIH, \\ Bethesda, Maryland, 20892 USA; ${ }^{3}$ Veterinary Resources Program, National Center for Research Resources, NIH, Bethesda, \\ Maryland, 20892 USA; $^{4}$ Office of the Director, NIH, Bethesda, Maryland, 20892 USA and Department of Microbiology and \\ Immunology, University of California, San Francisco, California 94143 USA
}

Transgenic mice expressing wild-type murine $p 53$ under the control of the mouse mammary tumor virus long terminal repeat (MMTV LTR) undergo progressive renal failure due to abnormal kidney development. Similar phenotypes are observed in two transgenic lines that express wild-type p53 within the ureteric bud but not in transgenic animals expressing a dominant-negative p53 mutant allele. Defective differentiation of the ureteric bud, as evidenced by altered marker expression during development, accompanies expression of the $p 53$ transgene. At E17.5-18.5, metanephric mesenchymal cells undergo high rates of apoptosis, and fewer cells than normal are converted to tubular epithelium. As a result, p53 transgenic kidneys grow to only half of their expected size and contain about half of the normal number of nephrons, with compensatory hypertrophy of the glomeruli. In this setting, rather than arrest the cell cycle or induce apoptosis directly, abnormally high levels of wild-type p53 appear to alter cellular differentiation in embryonic ureteric buds and cause secondary effects (apoptosis and inefficient conversion to epithelium) in the adjacent undifferentiated mesenchyme.

[Key Words: p53; transgenic mice; kidney development; ureteric bud]

Received December 13, 1995; revised version accepted February 15, 1996.

The $p 53$ tumor suppressor gene encodes a nuclear phosphoprotein that influences many important cellular functions, including transcription, DNA repair, cell cycle progression, and apoptosis (Clarke et al. 1993; Lowe et al. 1993b; Greenblatt et al. 1994; Jayaraman and Prives 1995; Lee et al. 1995; Reed et al. 1995; Thut et al. 1995). Loss of these functions, because of deletion or dominantnegative mutations of $p 53$, is commonly associated with the generation of human and experimental neoplasms (Greenblatt et al. 1994) and may prevent normal responses to DNA damaging agents, including anti-cancer therapies (Lowe et al. 1993a, 1994; Bergh et al. 1995). Despite the several prominent roles attributed to the gene, mice generated by targeted mutagenesis that lack p53 usually appear to undergo normal development (Donehower et al. 1992; Jacks et al. 1994; Purdie et al. 1994), save for a minority of female embryos with exencephaly (Sah et al. 1995). With time, however, p53-deficient animals exhibit a variety of malignant tumors, most often $T$ cell lymphomas and sarcomas (Donehower

${ }^{5}$ Corresponding author. et al. 1992; Jacks et al. 1994; Purdie et al. 1994), corroborating many other lines of evidence that justify calling p53 a tumor suppressor gene (Greenblatt et al. 1994).

We have recently begun to study the contribution made by $p 53$ mutations to multistep carcinogenesis by showing that the inheritance of two null alleles of $p 53$ accelerates the appearance of mammary tumors in mice carrying an oncogenic transgene (Donehower et al. 1995). This transgene, which includes the Wnt-1 proto-oncogene linked to the mouse mammary tumor virus long terminal repeat (MMTV LTR), normally induces breast carcinomas through a stochastic process that does not appear to include mutation of the $p 53$ gene. When accompanied by a deficiency of $p 53$, however, the Wnt-1 transgene induces mammary tumors much earlier than usual, in both male and female animals, and the tumors have altered properties: reduced stroma, more anaplastic cells, a higher degree of aneuploidy, and a greater frequency of other chromosomal abnormalities (Donehower et al. 1995).

To pursue these findings, we have generated new lines of mice carrying transgenes composed of wild-type and a dominant-negative allele of $p 53$ under the control of the 
MMTV LTR, with the intention of measuring their effects on Wnt-1-initiated mammary tumorigenesis, in the presence or absence of endogenous p53 genes. Early in the course of deriving these transgenic animals, however, we noted that two lines of transgenic mice carrying the wild-type $p 53$ transgene developed severe renal disease as a consequence of defective kidney development.

Reciprocal inductive events between two structures, the metanephric mesenchyme and the ureteric bud, are essential for proper kidney formation. The definitive kidney, also known as the metanephros, begins to develop at embryonic day 11 (hereafter denoted E11) in the mouse when the ureteric bud grows out from the mesonephric or Wolffian duct and enters collections of undifferentiated metanephric mesenchyme by E11.5 (Bard 1992). The ureteric bud arborizes within the mesenchyme, causing the metanephric mesenchyme to condense and differentiate at the tips of the branching ureteric bud. By E18.5, there is a range of observable differentiation within the kidney, with the most developed structures located toward the center of the gland and the least differentiated elements positioned at the periphery.

Once induced by the ureteric bud, the metanephric mesenchyme first differentiates into a comma-shaped body, which then elongates and further differentiates into an S-shaped body. Eventually each S-shaped body fuses with the portion of the ureteric bud that induced it. Capillaries invade the most proximal segment of the $\mathrm{S}$-shaped bodies to form the glomeruli, the structures in which filtration of the blood occurs. More distal portions of the S-shaped bodies become the proximal and distal tubules, sites for reabsorption from and excretion into the glomerular filtrate. Ureteric bud derivatives form the collecting tubules, where the urine is concentrated. Each nephron, the functional unit of the kidney, is thus composed of a glomerulus, proximal, distal, and collecting tubules, and produces urine. Urine ultimately drains through a single duct, the ureter, to collect in the bladder.

In this report we describe the unexpected renal phenotype of wild-type $p 53$ transgenic mice and present evidence suggesting that ectopic expression of wild-type p53 disorders differentiation of the ureteric bud and augments apoptosis in adjacent metanephric mesenchyme. As a result, the kidneys from wild-type p53 transgenic mice are small, contain half the normal number of nephrons, and are susceptible to progressive functional and anatomic derangement. These findings, in conjunction with other recent reports (Jones et al. 1995; Montes de Oca Luna et al. 1995), indicate that normal development of vertebrate organisms is more vulnerable to excessive amounts of p53 than to deficiencies.

\section{Results}

Wild-type, but not mutant, p53 transgenic mice exhibit a predominant phenotype within the kidney

We constructed mice that express either a wild-type or a dominant-negative mutant $(A 135 \mathrm{~V})$ p53 allele (Michalovitz et al. 1990; Milner and Medcalf 1990) under the control of the MMTV LTR promoter/enhancer (Fig. 1A), with the initial purpose of crossing these mice to Wnt-1 transgenic mice either containing or lacking an endogenous $p 53$ gene (see introductory section). To improve expression from the $p 53$ transgenes, we reinserted intron 4 into its proper position (see Materials and methods), as this intron contains an enhancer protein-binding site (Beenken et al. 1991). The polyadenylation signal was derived from the SV40 early region.

Six wild-type and 10 mutant p53 transgenic founder animals were obtained, and each was bred separately to nontransgenic mice to establish lines of $p 53$ transgenic mice. $F_{1}$ males and females were observed for up to 1 year for evidence of mammary gland pathology. No mammary tumors arose in any mutant p53 transgenic mice, although other tumor types were observed occasionally (data not shown). During this period of observation, wild-type $p 53$ transgenic mice derived from two different founder animals (designated lines B and C) died from apparent renal failure. Transgenic mice descended from the other four wild-type $p 53$ transgenic founder mice did not develop kidney disease, nor did any of the transgenic mice carrying the mutant $p 53$ transgene.

We tested for the expression of the $p 53$ transgene in the kidneys of transgenic animals by Northern blotting, which distinguishes the endogenous $p 53$ transcript from that of the transgene based on their different sizes (Fig. $1 \mathrm{~B}, \mathrm{C}$. In kidneys from line B animals, RNA from the $p 53$ transgene was most abundant during embryogenesis and declined with age (Fig. 1B). A major transgenic transcript of the expected size $(1.8 \mathrm{~kb})$ was present at $\mathrm{E} 18.5$ but was barely detectable by 3 weeks of age (Fig. 1B). Kidney expression of the wild-type p53 transgene remained low throughout the life of transgenic animals (data not shown). In contrast, high levels of transgenic RNA were present in the kidneys of mutant $p 53$ transgenic mice up to several months of age (data not shown; see Discussion). Expression of the wild-type $p 53$ transgene was observed only in mice from lines B and C, and not in mice descended from the four remaining wild-type $p 53$ transgenic founders, consistent with the absence of renal disease (data not shown). Northern blotting of RNA from additional organs demonstrated that the $p 53$ transgene was expressed in the brain, lung, and salivary gland in line B animals (Fig. 1C). Transgenic RNA was found at similar levels in these organs from line $\mathrm{C}$ animals and at lower levels in the mammary glands of female mice /data not shown).

More $p 53$ transgenic animals from line B died of endstage renal disease than did mice from line $\mathrm{C}$ (see below). To generate $p 53$ transgenic mice with a more severe phenotype from line $\mathrm{C}$, we bred the line $\mathrm{C} p 53$ transgene to homozygosity. Homozygous line $\mathrm{C}$ mice were fertile and were used in subsequent studies presented below. We have attempted to do the same with $p 53$ transgenic mice from line B. However, few homozygous line B mice survived long enough to breed or to permit a complete evaluation of renal function. A summary of some of the 


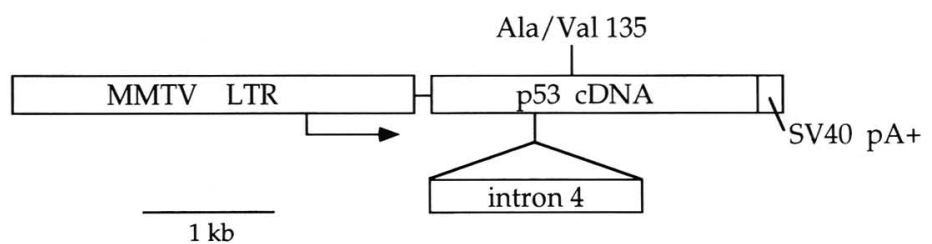

B

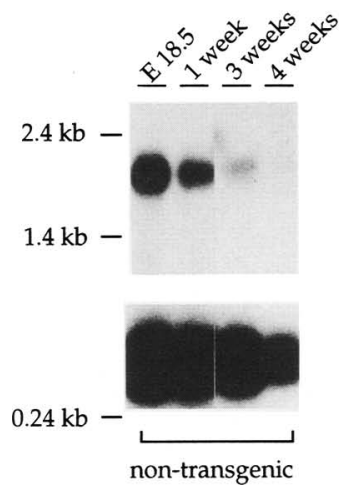

C

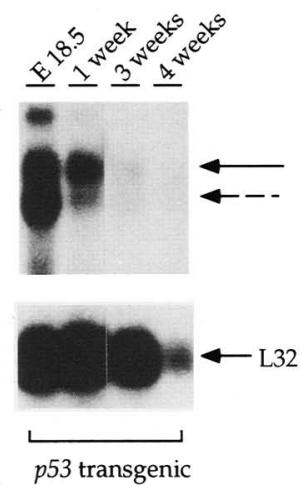

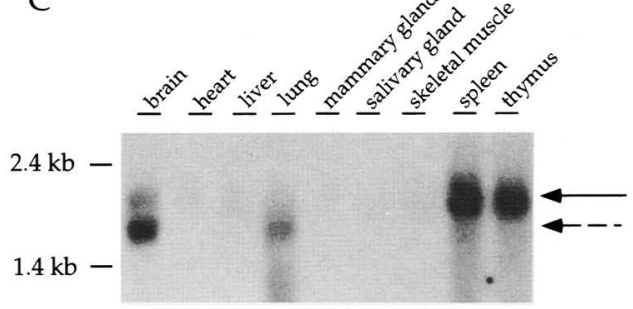

Figure 1. $p 53$ transgenic design and expression. (A) p53 transgene design. The MMTV LTR drives expression of a murine p53 cDNA into which intron 4 was replaced. Transgenic mice were generated with either a wild-type $p 53$ cDNA or one encoding a dominantnegative, temperature-sensitive allele, Val 135. The SV40 early region polyadenylation signal was used. $(B \mid$ Northern blot measuring expression of the wild-type $p 53$ transgene in the kidney as a function of age (E18.5-4 months) in line B. Poly $(\mathrm{A})^{+}$RNA was isolated from $100 \mathrm{mg}$ of kidneys of the indicated genotype and age. In some cases, kidneys from multiple animals were pooled. The band corresponding to endogenous $p 53 \mathrm{RNA}(2.0 \mathrm{~kb})$ is indicated with an arrow, and that derived from the transgene $(1.8 \mathrm{~kb})$ is designated with a broken arrow. The Northern blot was rehybridized with a probe for L32 ribosomal protein mRNA to monitor the amount and integrity of the RNA in each lane. $(C)$ Expression of the line B p53 transgene in other organs. Poly(A) ${ }^{+}$RNA was isolated from the indicated organs of a 3-month-old line B p53 transgenic mouse. As in $B$, the arrow indicates the endogenous p53 transcript; and the broken arrow designates the $p 53$ transgenic transcript. This Northern blot was not hybridized with a probe for L32 ribosomal protein mRNA, because the endogenous $p 53$ transcript serves as an internal control for RNA integrity.

pathophysiological findings observed in these wild-type p53 transgenic mice is given in Table 1.

The presence of end-stage renal disease in two separate lines of p53 transgenic mice, as well as the high levels of transgene-derived RNA in embryonic kidneys, prompted us to examine renal development in these mice. As early as 3 days after birth, p53 transgenic animals could be identified based on kidney mass. Kidneys from p53 transgenic mice weighed half as much as those from nontransgenic sibling controls throughout the first several weeks of life (Fig. 2A). The weight of kidneys from homozygous line $C$ animals was similar to that of kidneys from heterozygous line B mice (Fig. 2B). The decrease in kidney mass in p53 transgenic mice was proportional to a decrease in the number of nephrons, but the average glomerular volumes were greater in p53 transgenic kidneys (Table 1). The glomeruli in p53 transgenic mice appeared to have hypertrophied in response to the decrease in glomerular number (Table 1).

To compare renal function in p53 transgenic mice from lines $\mathrm{B}$ and $\mathrm{C}$ to that of their nontransgenic siblings, blood and urine samples were collected every 6-8 weeks for 10 months. Blood urea nitrogen (BUN) levels and urine protein/creatinine ratios are standard mea- surements of kidney function, with normal values occupying a narrow range. BUN levels were increased in line B p53 transgenic mice more often than in heterozygous line C p53 transgenic mice (Fig. 3), and BUN levels in adult mice homozygous for the line $\mathrm{C}$ transgene were consistently elevated (Fig. 3C). In general, urine protein/ creatinine ratios paralleled BUN values (Table 1 ; data not shown).

Mice derived from two mutant p53 transgenic founders expressed the mutant $p 53$ transgene in the kidney but did not develop renal disease as assessed by kidney mass or BUN values (data not shown). Thus, the effects of expression of MMTV-driven p53 transgenes are specific to wild-type $p 53$. We attempted to suppress the kidney phenotype produced by the line B transgene by breeding these mice to those carrying the $A 135 \mathrm{~V} p 53$ transgene. However, like the line B p53 transgenic mice, the bitransgenic animals had small kidneys. The failure of the mutant p53 transgene to suppress the wild-type transgene may reflect the relatively weak dominant-negative effects of the Val 135 allele (Michalovitz et al. 1990; Milner and Medcalf 1990) or inadequate levels of expression of the $A 135 \mathrm{~V}$ transgene.

The histopathological manifestations of the renal dis- 
Table 1. Abnormal renal anatomy and physiology in two lines of wild-type p53 transgenic mice

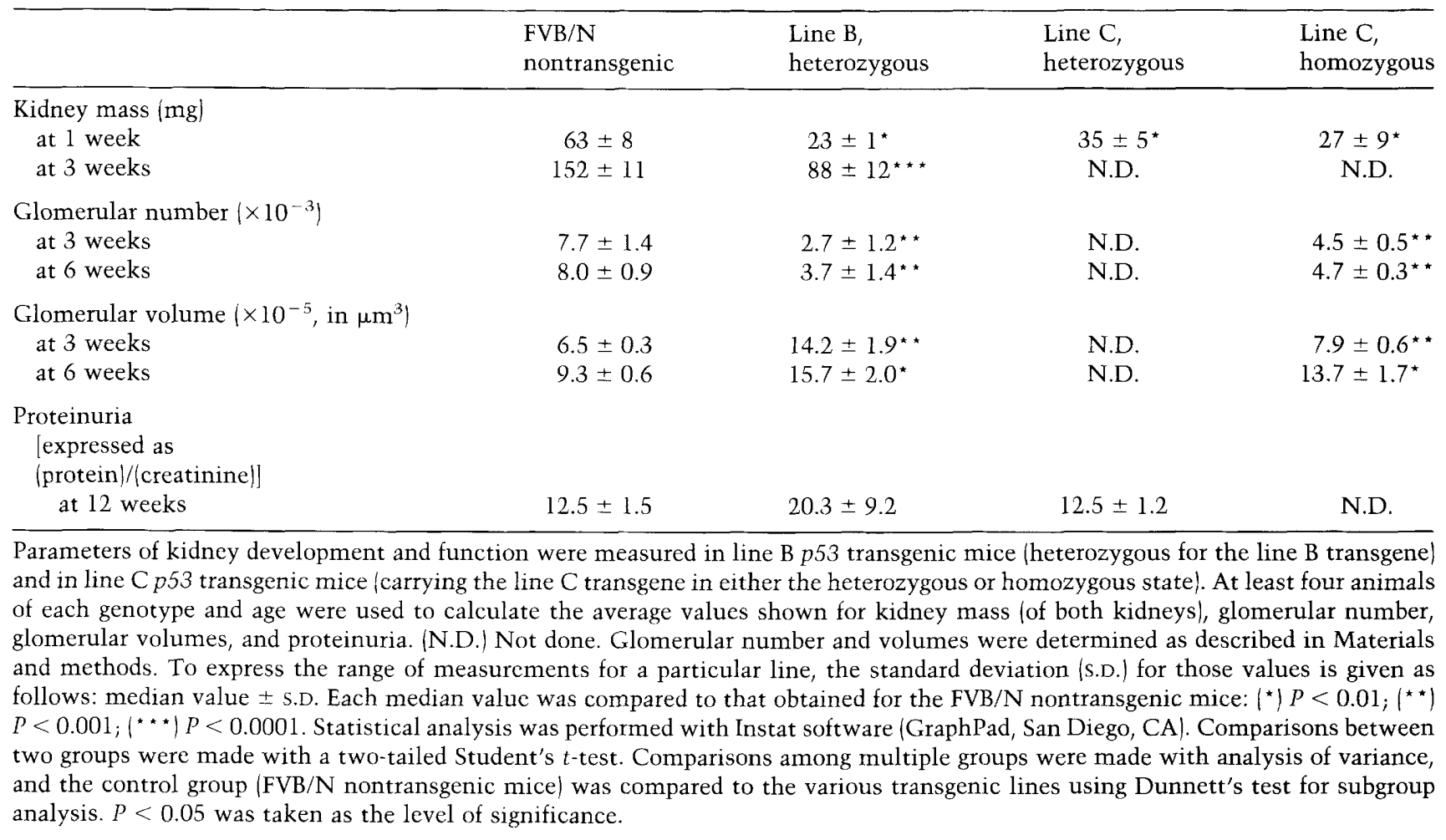

ease observed in wild-type p53 transgenic mice had glomerular, tubular, and interstitial components (Fig. 4AF). Kidneys from lines B and C p53 transgenic mice with advanced disease contained fibrotic glomeruli of increased size /cf. examples from line B p53 transgenic mice in Fig. 4, B and D, to those from nontransgenic mice in Fig. 4, A and C). The glomerular mesangial compartment was expanded by accumulated extracellular matrix protein (Fig. 4, cf. E and F). Synechiae, or adhesions of the glomerular tuft to Bowman's capsule, were present (Fig. 4F). Most glomeruli manifested global glomerulosclerosis, but with early disease occasional glomeruli showed sclerosis confined to segments of the capillary tuft (data not shown). Glomerular cell numbers remained similar to that of nontransgenic FVB/N mice (Fig. 4E, F), indicating that the glomerular lesions were not inflammatory in nature. Immunoglobulin deposition was present in sclerotic glomeruli, with prominent IgM but lesser amounts of IgA and IgG (data not shown). This complement of immunoglobulins suggests a nonimmune-mediated renal disease, with nonspecific trapping of antibodies by a dysfunctional mesangium. Tubules were characterized by protein reabsorption droplets, proteinaceous casts, and focal dilation (Fig. 4, cf. A and B). Areas of marked interstitial fibrosis and mild multifocal perivascular mononuclear cell infiltrates were present. Ultrastructural changes included mesangial expansion, with increased extracellular matrix material, and effacement of glomerular epithelial cell foot processes /data not shown). p53 transgenic mice are predisposed to renal insufficiency because of defective development of the kidney

The abnormality in kidney mass as early as 3 days after birth suggested that embryonic renal development was impaired in p53 transgenic mice. At E16.5, kidneys from p53 transgenic and nontransgenic embryonic littermates were difficult to distinguish histologically. However, by E18.5, kidneys from $p 53$ transgenic animals could be distinguished unequivocally by a decrease in the number of undifferentiated mesenchymal cells, usually present at that age at the perimeter of the developing kidney (data not shown). At 1 week of age, kidneys from nontransgenic littermates still contained undifferentiated mesenchymal cells (Fig. 4G). These uncommitted cells were rarely seen in kidneys from line B p53 transgenic animals 1 week after birth (Fig. $4 \mathrm{H}$ ), whereas mice homozygous for the line $\mathrm{C}$ transgene had fewer undifferentiated mesenchymal cells than mice heterozygous for the same transgene (Fig. 4I,J). Kidneys from heterozygous line B transgenic mice possessed even fewer uncommitted mesenchymal cells than those from homozygous line $\mathrm{C}$ transgenic mice at this age (Fig. 4, cf. $\mathrm{H}$ and J).

Undifferentiated metanephric mesenchyme normally undergoes differentiation into proximal nephron segments and eventually fuses with the ureteric bud outgrowth that induced its differentiation to complete the formation of functional nephrons (Bard 1992). Therefore, the absence of uncommitted cells at E18.5 represents a 
A

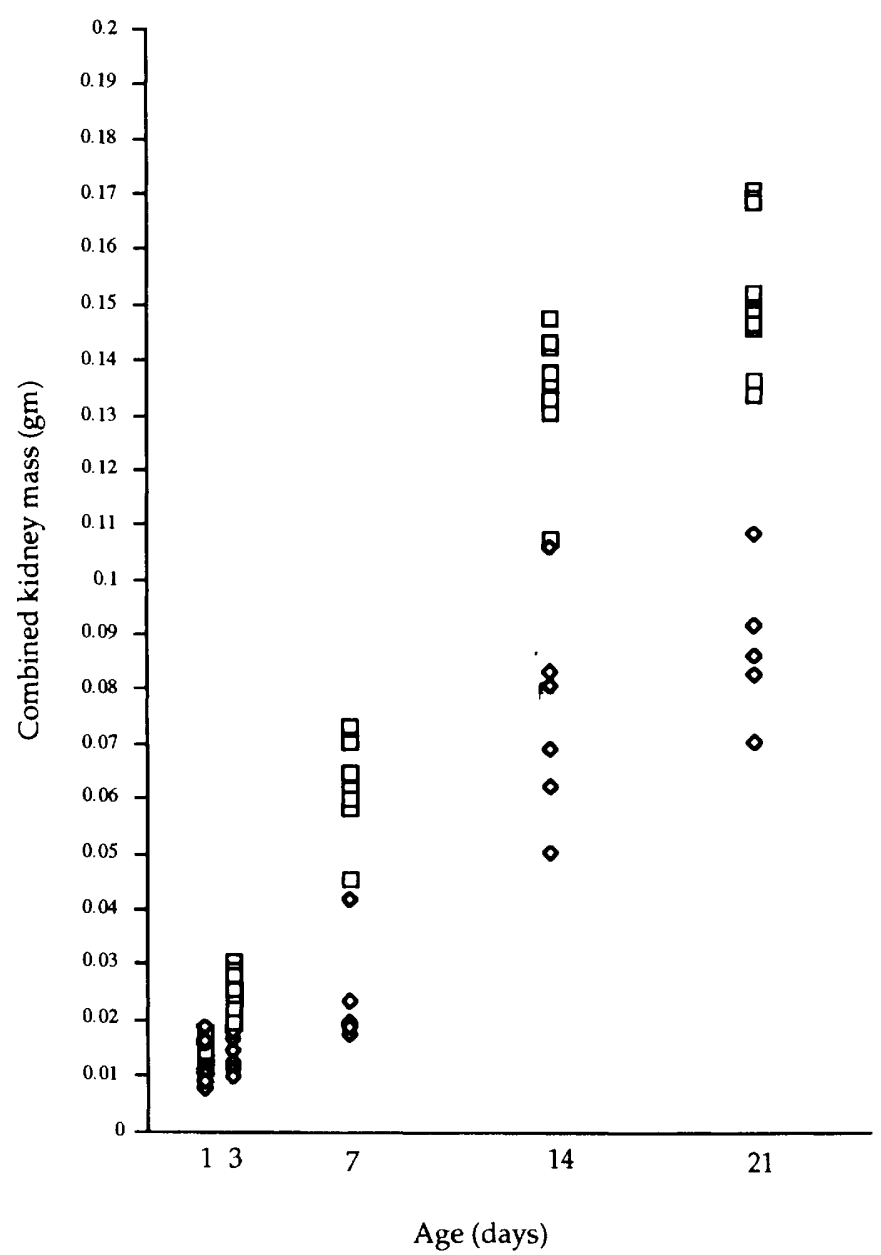

B

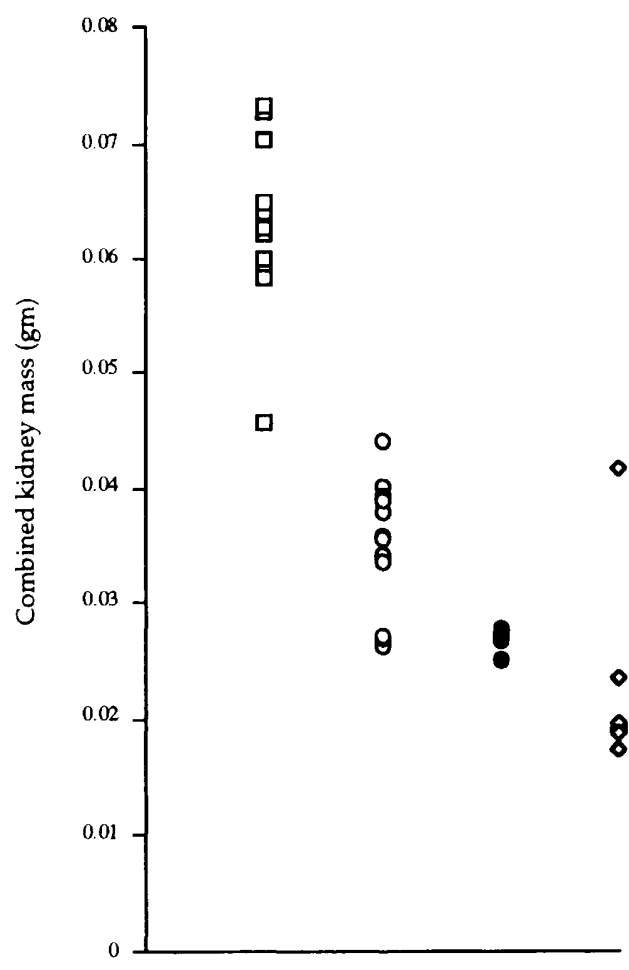

Mouse Strain

Figure 2. Kidneys from wild-type $p 53$ transgenic animals are abnormally small. $(A)$ The combined kidney masses from nontransgenic littermates and line B p53 transgenic mice as a function of age. Both kidneys were weighed from animals of the indicated genotypes, at ages that ranged from the day of birth to 3 weeks. ( $\square)$ Nontransgenic controls; $(\diamond)$ line B p53 transgenic mice, heterozygous for the transgene. $(B)$ The combined kidney masses from nontransgenic littermates, heterozygous or homozygous line $C p 53$ transgenic mice, and heterozygous line B p53 transgenic mice. Both kidneys were weighed from animals of the indicated genotypes at 1 week of age. The genotypes are as follows: $(\square)$ nontransgenic littermates; $(O)$ heterozygous line $\mathrm{C} p 53$ transgenic mice; (O) homozygous line $\mathrm{C} p 53$ transgenic mice; $(\diamond)$ heterozygous line B p53 transgenic mice.

loss of potential nephrons. The extent of this loss is reflected in the decreased kidney mass and glomerular number observed in $p 53$ transgenic mice.

Increased numbers of apoptotic cells are present within the undifferentiated mesenchyme at E17.5 in wild-type $\mathrm{p} 53$ transgenic mice

The severe reduction in numbers of uncommitted metanephric mesenchymal cells at E18.5 suggested that these cells could be dying at an earlier age. We conducted TdT-mediated dUTP nick end labeling (TUNEL) assays within embryonic kidneys of wild-type $p 53$ transgenic animals to examine the extent of apoptosis prior to E18.5. Transgenic kidneys at E16.5 contained about twice the number of apoptotic nuclei as nontransgenic kidneys (data not shown). By E17.5, there were $\sim 10$-fold more apoptotic nuclei in transgenic kidneys than in those from nontransgenic animals (Fig. 4K,L). These dying cells were grouped in clusters and were confined almost exclusively to the nephrogenic zone of the developing kidneys, which contains the undifferentiated mesenchyme.

To confirm that the TUNEL assay identified apoptotic nuclei, we performed electron microscopy on p53 transgenic and nontransgenic kidneys to identify ultrastructural hallmarks of apoptosis. Toluidine blue staining of the nephrogenic zone in $p 53$ transgenic kidneys identified groups of pyknotic nuclei at E17.5, similar to the TUNEL-positive nuclei described above (Fig. 5B). Thin 

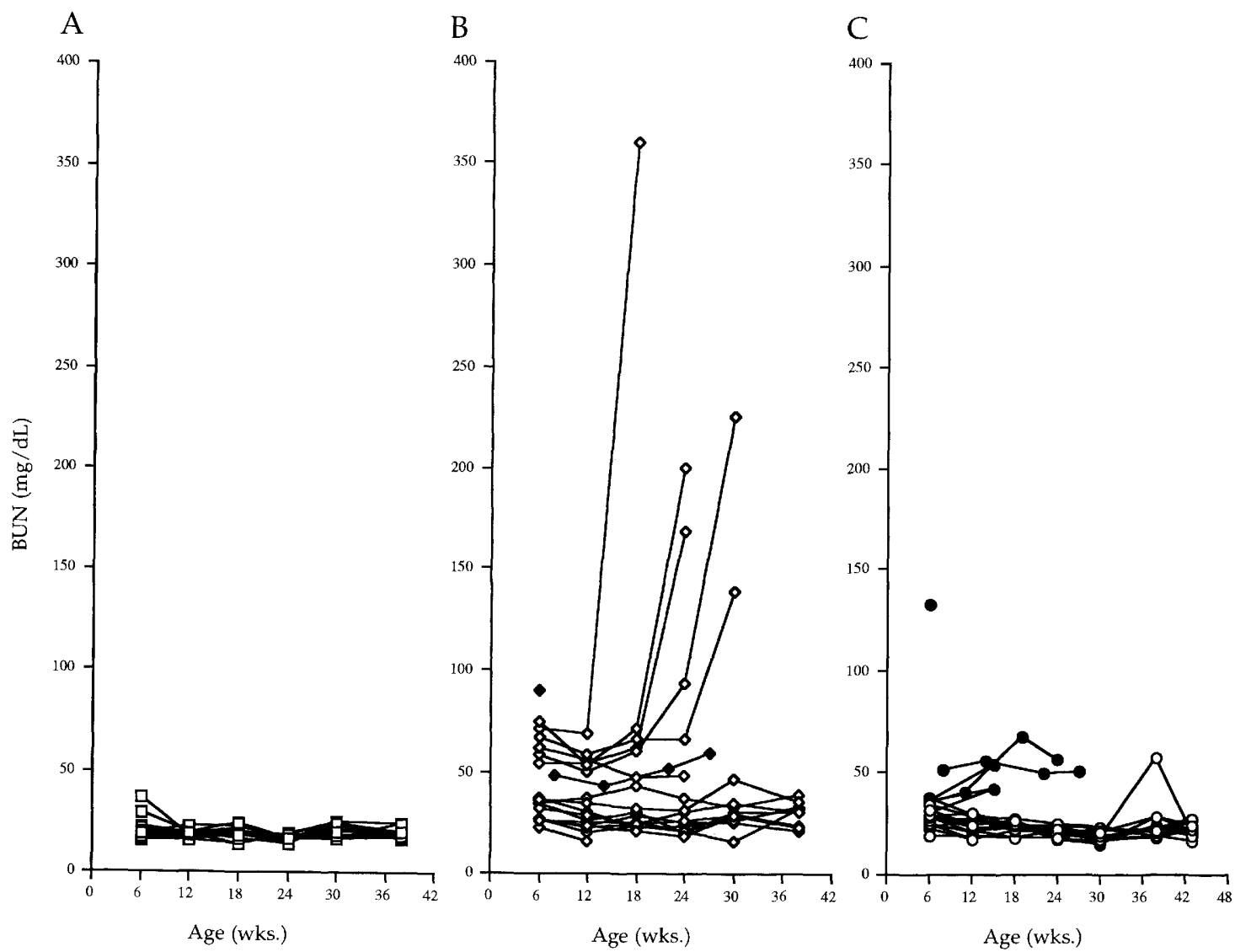

Figure 3. BUN measurements in p53 transgenic mice and controls. Mice were bled approximately every 6 weeks for $>10$ months, and BUN levels were determined. (A) BUN values from 10 male and 8 female nontransgenic control mice $(\square)$. (B) BUN measurements from 11 male and 6 female heterozygous line B p53 transgenic mice $(\diamond)$ and from 4 male homozygous line B p53 transgenic mice $(\diamond) .(C)$ BUN levels from six male and eight female heterozygous line $\mathrm{C}$ p53 transgenic mice $|O|$ and from four male and five female homozygous line $\mathrm{C}$ p53 transgenic mice

sections were prepared from selected areas of $p 53$ transgenic or nontransgenic kidneys for electron microscopy, which confirmed the presence of apoptotic nuclei at the periphery of $p 53$ transgenic kidneys at E17.5 (Fig. 5C). Apoptotic cells could be identified by the presence of condensed chromatin, early nuclear fragmentation, and clustering of organelles (Fig. 5C). Thus, the absence of uncommitted mesenchymal cells at E18.5 is a result of earlier massive apoptosis.

The simplest explanation for apoptosis of undifferentiated metanephric mesenchymal cells is that they express the $p 53$ transgene and die as a direct consequence of transgene expression. To address this possibility, in situ hybridizations were performed to identify the cell types that express the p53 transgene (Fig. 6). Because differentiating mesenchymal cells express endogenous $p 53$ at the comma and S-shaped tubule stages (Schmid et al. 1991), a probe complementary to the SV40 polyadenylation site was used to identify $p 53$ transgenic transcripts specifically. Throughout the time period examined, E14.5-E18.5, p53 transgenic RNA was detected only in cells of the ureteric bud (Fig. 6). Although transgene-derived RNA was readily observed at E14.5, levels were noticeably greater at E16.5 and still higher at E18.5. Because p53 transgenic RNA was observed only in cells of the ureteric bud, the undifferentiated mesenchymal cells appeared to die as an indirect consequence of transgene expression. The observation that the mesenchymal cells die in small clusters suggests that these cells require a survival and/or inductive signal at a precisely defined point. If these cells do not receive such a signal, they die because of apoptosis. Alternatively, expression of the $p 53$ transgene might produce a factor that induces apoptosis in the undifferentiated mesenchymal cells.

\section{Differentiation of the ureteric bud is defective in 553 transgenic kidneys}

Histologic examination of kidneys ranging in age from E14.5 to several weeks after birth failed to identify any obvious defects in ureteric bud growth or branching in p53 transgenic animals compared to nontransgenic controls. Derivatives of the ureteric bud were seen to be arborized at the periphery of embryonic kidneys at E14.5 (Fig. 6A), as well as at older ages (data not shown). To examine more precisely the ability of cells within the 
Figure 4. Kidney histology of p53 transgenic and nontransgenic mice. $(A-F)$ Renal pathology at 6 months of age. (A) Normal kidney from a 6-month-old nontransgenic mouse $150 \times$, PAS stain). (B) Kidney from a 6-month-old line B p53 transgenic mouse showing enlarged glomeruli (arrowheads|, with globally increased mesangial matrix, and dilated tubules $\left({ }^{*}\right)$ occupied by eosinophilic proteinacious material (50x, PAS stain). $(C)$ Normal kidney from a 6-month-old nontransgenic mouse $(50 \times$, Masson's trichrome stain). (D) Kidney from a 6-month-old line B p53 transgenic mouse displaying enlarged glomeruli and bands of interstitial fibrosis, (arrowhead) (50x, Masson's trichrome stain). (E) Higher power view of normal glomeruli from a 6-month-old nontransgenic mouse $(200 \times$, Masson's trichrome stain). $(F)$ Higher power view of a glomerulus from a 6-month-old line B p53 transgenic mouse showing diffuse increase in blue-staining mesangial matrix (200×, Masson's trichrome stain). \{G-I) Nephrogenic zones of kidneys from 1-week-old mice (50×, hematoxylin and eosin stain). Uncommitted mesenchymal cells can be identified as purplestaining nuclei in the periphery of the kidney that have not yet assembled into immature glomeruli. $(G)$ Kidney from a nontransgenic mouse containing immature glomeruli (arrowheads) in the outermost cortical layer. $(H)$ Kidney from a line B p53 transgenic mouse with fewer glomeruli (none are present in this field) and dilated collecting tubules $\left.{ }^{*}\right)$. (I) Kidney from a heterozygous line C p53 transgenic mouse demonstrating occasional immature glomeruli (arrowhead) within the nephrogenic zone. $(J)$ Kidney from a homozygous line $\mathrm{C}$ p53 transgenic mouse lacking immature glomeruli. A dilated collecting tubule. $(K, L)$ Apoptosis in kidneys from E17.5 mice (100× TUNEL assay visualized by diaminobenzidine staining with methyl green counterstain). $(K)$ Kidney from a nontransgenic mouse with no TUNEL-positive cells. (L) Kidney from a line B p53 transgenic mouse containing many TUNEL-positive cells (arrowheads).

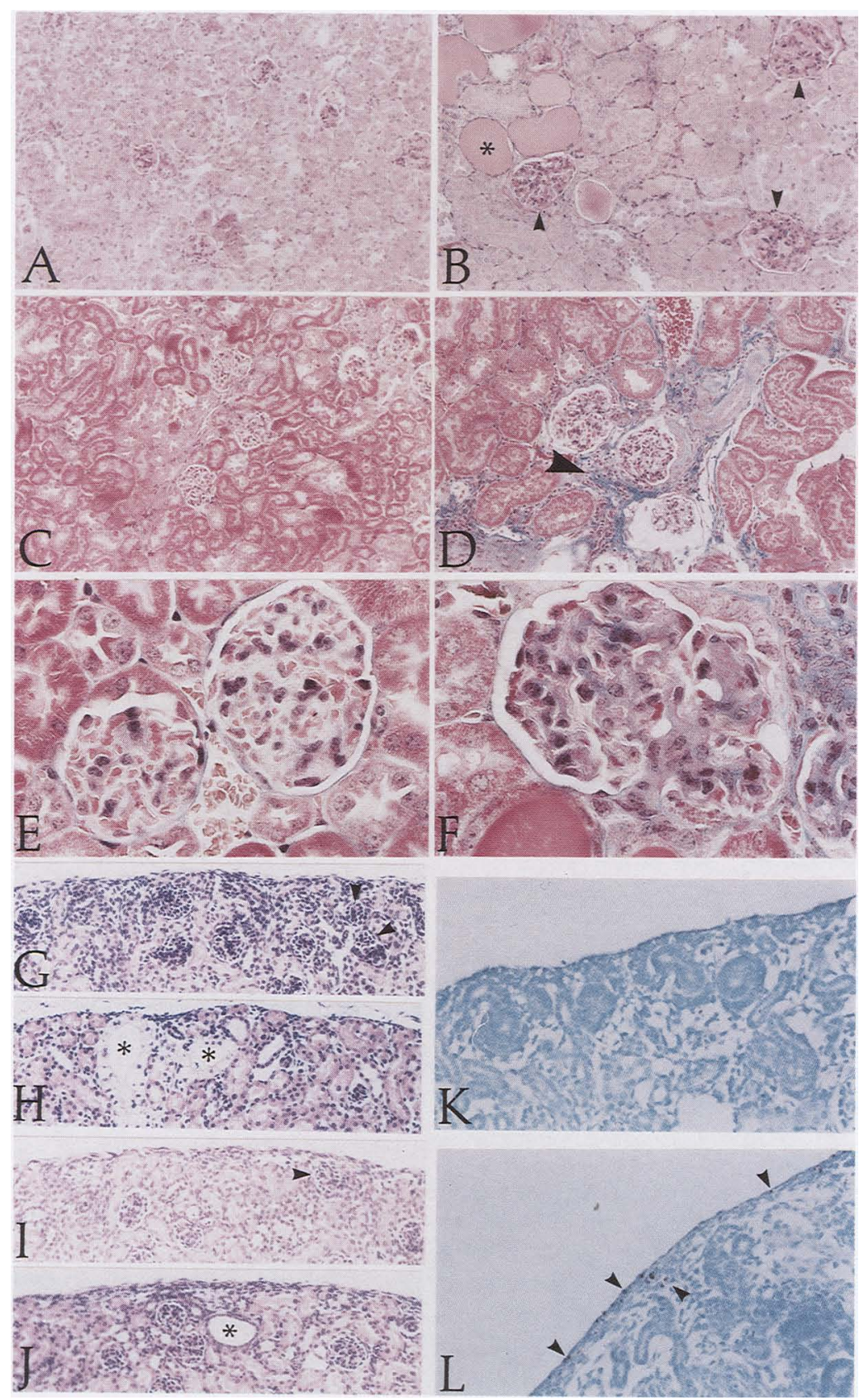

ureteric bud to pass through $G_{1}$ and enter $S$ phase, BrdU labeling was performed. In both p53 transgenic and in nontransgenic kidneys, cells derived from the ureteric bud incorporated BrdU as efficiently as other cells within the kidney throughout the age range tested (E16.5 through 3 days postpartum), suggesting that cells from the ureteric bud are not undergoing $G_{1}$ cell cycle arrest (data not shown). In further support of this observation, Northern blots demonstrated no increase in RNA levels of $p 21 / W A F 1 / C i p 1$ (data not shown), a gene that is induced by $p 53$ and contributes to $G_{1}$ cell cycle arrest (ElDiery et al. 1993; Harper et al. 1993).

The inability of the ureteric bud to induce the meta- nephric mesenchyme properly could reflect inappropriate differentiation of the ureteric bud attributable to expression of the $p 53$ transgene. To test this possibility, we examined several markers of kidney differentiation in developing $p 53$ transgenic and nontransgenic kidneys. At E11.5, c-ret RNA is found throughout the length of the ureteric bud, but expression is confined later to the tips of the ureteric bud (Pachnis et al. 1993). In p53 transgenic kidneys, however, c-ret expression is not localized to the ureteric bud tips at E14.5 (Fig. 7B). By E16.5, some c-ret RNA is concentrated at the tips, but it is not present at the ends of the ureteric bud along the entire perimeter of the kidney (Fig. 7D). By E18.5, c-ret is ex- 

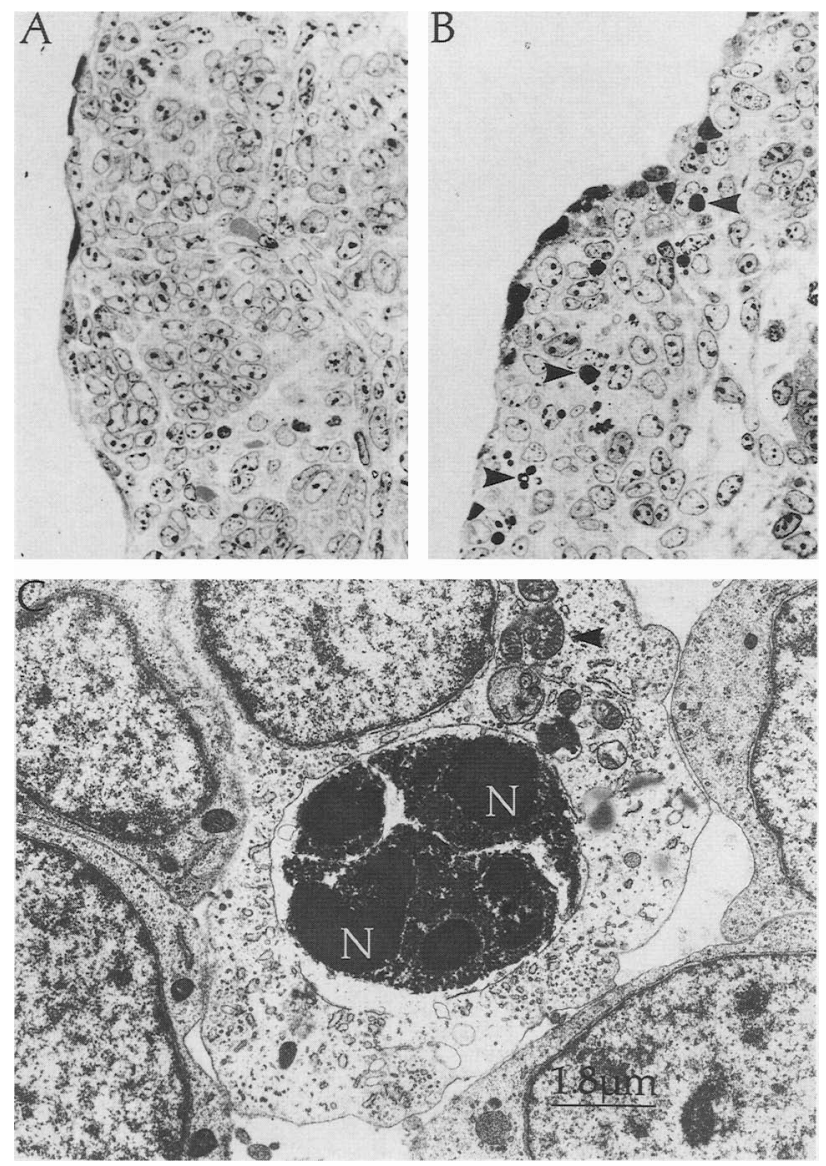

Figure 5. Demonstration of apoptotic mesenchymal cells by toluidine blue staining and electron microscopy of p53 transgenic kidneys at E17.5. (A) Kidney from a nontransgenic mouse (630x, toluidine blue stain). (B) Kidney from a line B p53 transgenic mouse, demonstrating subcapsular apoptotic cells indicated with arrowheads $(630 \times$, toluidine blue stain). (C) Electron micrograph demonstrating an apoptotic cell from the periphery of the renal cortex of an E17.5 heterozygous line B p53 transgenic mouse. Note the presence of condensed chromatin and early nuclear fragmentation $(\mathrm{N})$ and clustered cytoplasmic organelles (arrowhead). The adjacent cells show no evidence of apoptosis. Magnification, 11, 375×.

pressed throughout the length of the ureteric bud, with very little at the tips (Fig. $7 F$ ), indicating a significant reordering of the differentiation process in the expanding ureteric bud system.

A second marker for derivatives of the ureteric bud is detected by staining with Dolichos biflorus (DB) lectin. DB lectin binds polysaccharides on an unidentified protein that is expressed exclusively in collecting tubules, derivatives of the ureteric bud. DB lectin binding was similar in E14.5 and E16.5 kidneys from nontransgenic and line B p53 transgenic mice (Fig. 8A,B, and data not shown). Expression of this marker deteriorated rapidly, however, and DB lectin staining was almost completely absent from the kidneys from $p 53$ transgenic mice at E18.5 (Fig. 8C,D). Similarly, aquaporin 2, a water channel expressed throughout renal collecting tubules /Sa- bolic et al. 1995), was almost undetectable in p53 transgenic kidneys at E18.5 (Fig. 8F). Thus, expression of three ureteric bud markers-c-ret, the glycoprotein that binds DB lectin, and aquaporin 2-is defective in p53 transgenic kidneys.

Although ureteric bud markers were affected in p53 transgenic mice, markers for differentiating mesenchyme were expressed normally. WT-1, the gene mutated in Wilms' tumors, is an early marker for committed mesenchyme (Kreidberg et al. 1993). WT-1 RNA can be observed by E12.5 and is restricted to podocytes surrounding glomeruli by E16.5 (Bard 1992; Pritchard-Jones et al. 1990). This expression pattern was observed in both nontransgenic and $p 53$ transgenic kidneys (Fig. $7 \mathrm{G}, \mathrm{H}$ ). A second mesenchymal differentiation marker was also unaffected in p53 transgenic kidneys. Lotus lectin binds polysaccharides on an unidentified protein that is expressed on proximal tubules, derivatives of the induced mesenchyme. At E18.5, lotus lectin immunofluorescence was equivalent in both transgenic and nontransgenic kidneys (Fig. 8G,H).

Thus, it appears that during the early stages of kidney development, induction takes place normally, so that about half of the expected number of nephrons are produced in p53 transgenic kidneys. However, expression of the $p 53$ transgene in the ureteric bud from E14.5 to E18.5 causes altered differentiation of the bud system, abnormal inductive signaling, and loss of metanephric mesenchyme by apoptosis. The resulting kidneys grow to only half of their normal size.

\section{Discussion}

Transgenic mice expressing wild-type $p 53$ from an MMTV LTR are predisposed to the development of early, severe renal degeneration due to abnormal development of the kidney. p53 transgenic kidneys grow to only half of their expected size because of the loss of uncommitted mesenchymal cells, mainly at E17.5. These cells undergo apoptosis presumably because proper inductive signals are not produced from the abnormal ureteric bud. The loss of mesenchymal stem cells results in fewer glomeruli in p53 transgenic newborn mice, and these glomeruli undergo compensatory hypertrophy. Proteinuria appears as early as 2 weeks of age, with azotemia beginning at 6 weeks of age in some animals. Most affected glomeruli ultimately show global glomerulosclerosis, but a few have segmental lesions. As evidence of its improper differentiation, the embryonic ureteric bud fails to appropriately express several markers, including c-ret, the binding protein for DB lectin, and aquaporin 2 .

The effect of $p 53$ overexpression is specific to the wildtype $p 53$ transgene, as transgenic mice expressing a mutant $p 53$ allele have normal kidneys. In another system in which transgenic mice express wild-type $p 53$ within the lens, a phenotype of altered lens cell differentiation was rescued by creating bitransgenic mice which also expressed a mutant p53 transgene (Nakamura et al. 1995।. However, the degree of phenotypic rescue was dependent on the amount of mutant $p 53$ transgene expres- 

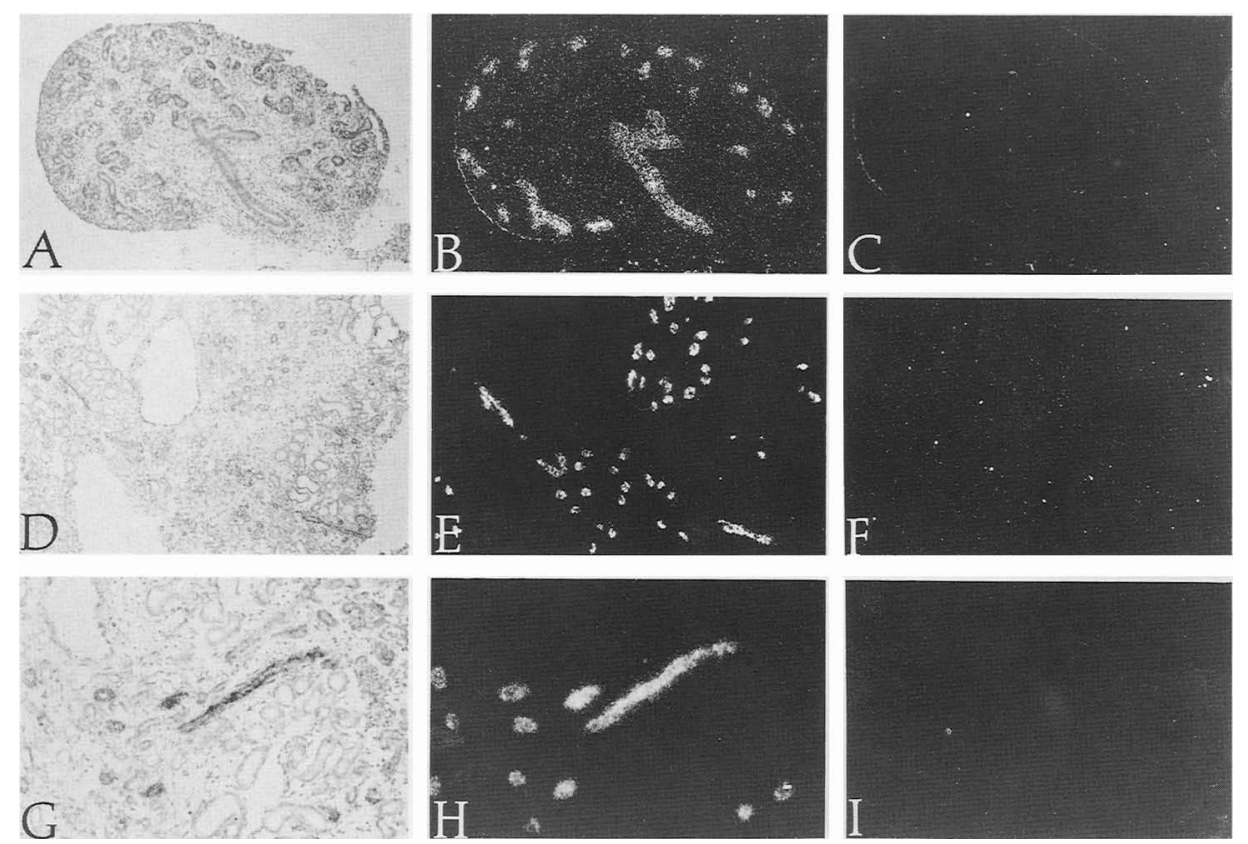

Figure 6. Expression of the p53 transgene in embryonic kidneys is confined to cells derived from the ureteric bud. The SV40 early region polyadenylation signal was used as the probe for in situ hybridizations to detect RNA from the p53 transgene specifically. All of the sections are taken from heterozygous line B p53 transgenic mice. $(A-C)$ E14.5 p53 transgenic kidneys $(25 \times)$. $(A)$ Tissue section stained with hematoxylin and eosin and seen under bright field. $(B, C)$ The same section viewed under dark field after hybridization with SV40 anti-sense probe $(B)$ or SV40 sense control probe $(C) .(D-F)$ E18.5 p53 transgenic kidneys $(25 \times)$. $(D)$ Tissue section stained with hematoxylin and eosin and seen under bright field. $(E, F)$ The same section viewed under dark field after hybridization with SV40 anti-sense probe $(E)$ or SV40 sense probe $(F) .(G-I)$ E18.5 p53 transgenic kidneys at higher power $(50 \times)$. $(G)$ Tissue section stained with hematoxylin and eosin and seen under bright field. $(H, I)$ The same section viewed under dark field after hybridization with SV40 anti-sense probe $(H)$ or SV40 sense probe $(I)$.

sion. In our experiments, the inability of the mutant $p 53$ transgene to rescue the small kidneys associated with the wild-type $p 53$ transgene may be attributable to the weak dominant-negative effects of the Val 135 allele, inadequate levels of mutant p53 in the ureteric bud, or both.

Expression of the wild-type $p 53$ transgene in the kidney fades with time (Fig. 1A), possibly as a result of the altered differentiation of the ureteric bud. Expression of the mutant p53 transgene, however, is maintained for many months in $A 135 \mathrm{~V} p 53$ transgenic animals (data not shown). Presumably the ureteric bud is unaffected despite expression of the Val 135 allele in $A 135 \mathrm{Vp} 53$ transgenic animals, and the kidneys develop normally.

Two individual lines of wild-type $p 53$ transgenic mice exhibit similar phenotypes. $p 53$ transgenic mice from one line (line B), display abnormal kidney development in the heterozygous state, whereas the mice derived from the other line (line C), exhibit a comparable phenotype in the homozygous state and a weaker phenotype in the heterozygous state. All p53 transgenic mice from lines B and $\mathrm{C}$ examined so far possess decreased amounts of metanephric mesenchyme late in embryogenesis, predisposing them to the development of end-stage renal disease. About $50 \%$ of the $p 53$ transgenic mice from line B and $45 \%$ of mice homozygous for the line $C$ transgene exhibit elevated BUN levels, indicating that renal func- tion is impaired in these animals. Despite the reduction in nephron number, renal function is adequate in some p53 transgenic mice, as evidenced by normal BUN levels. However the degree of loss of metanephric mesenchyme correlates with susceptibility to developing endstage renal disease, suggesting that decreased numbers of nephrons are largely responsible for the development of chronic renal failure.

The mechanism by which a decreased number of nephrons leads to end-stage renal disease has at least two components. First, fewer nephrons may predispose to renal disease, because of increased filtration loads within existing nephrons (Brenner et al. 1988). Conditions that reduce total glomerular filtration surface are associated with progressive renal disease characterized by focal segmental glomerulosclerosis (Hostetter et al. 1981) as observed in p53 transgenic mice. In addition, such changes have been seen in kidneys of adult rats subjected to reduction of renal mass (Howie et al. 1989). Second, those nephrons that do develop in p53 transgenic kidneys may not be normal. Serum albumin was found in the urine of p53 transgenic mice as early as two weeks after birth (data not shown), suggesting early functional compromise of the kidney. This may not be surprising considering the defects in marker expression.

Two outcomes have been described for cells in which wild-type $p 53$ is overexpressed: induction of apoptosis 
non-transgenic
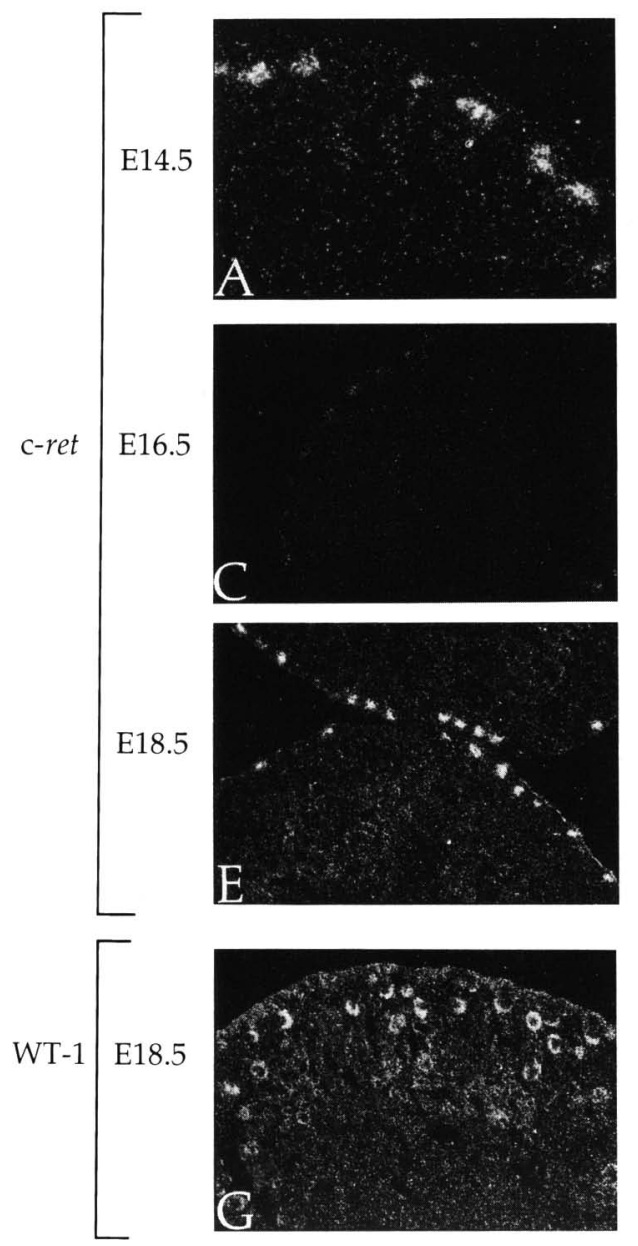

p53 transgenic
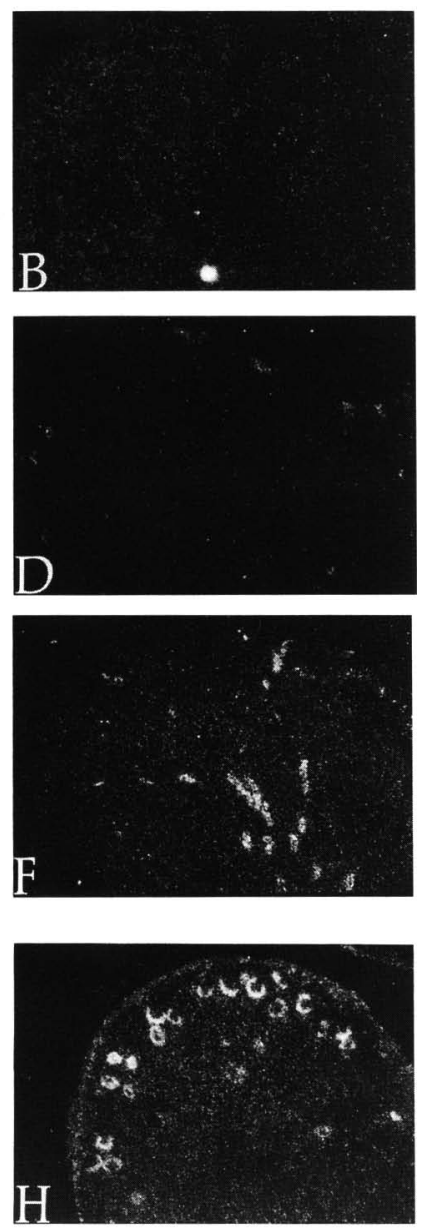

Figure 7. Tests by in situ hybridization for markers of differentiation of renal components. p53 transgenic kidneys were derived from heterozygous line B $p 53$ transgenic mice. Sense controls showed no signal for either probe (data not shown). $(A-F)$ Probe for c-ret, a marker for development of the ureteric bud. $(A, B)$ E14.5 kidneys $(50 \times$, dark field) from nontransgenic control $(A)$ and $p 53$ transgenic $(B)$ mice. $(C, D)$ E16.5 kidneys $(25 \times$, dark field) from nontransgenic control $(C)$ and $p 53$ transgenic $(D)$ mice. $(E, F)$ E18.5 kidneys $(25 \times$, dark field $)$ from nontransgenic control $\langle E\rangle$ and $p 53$ transgenic $(F)$ mice. $(G, H)$ Probe for WT1, a marker for renal epithelium. E18.5 kidneys $(25 \times$, dark field) from nontransgenic control $(G)$ and $p 53$ transgenic $(H)$ mice.
(Yonish-Rouach et al. 1991), or $\mathrm{G}_{1}$ cell cycle arrest following DNA damage (Kastan et al. 1991; Kuerbitz et al. 1992). In the p53 transgenic kidneys, there is little evidence that p53 acts in either of these modes to yield the observed phenotype. TUNEL assays revealed apoptosis only in the undifferentiated metanephric mesenchyme. Because these cells do not express the transgenic RNA at detectable levels, the p53 transgene cannot be directing apoptosis in these cells by a cell-autonomous mechanism. Neither is there evidence that p53 causes $G_{1}$ cell cycle arrest of transgene-expressing cells derived from the ureteric bud. In p53 transgenic animals, the ureteric bud continues to grow and branch throughout development and contains normal numbers of cells in S-phase. Thus, in this context, p53 functions in a novel way to generate the renal phenotype.

p53 may have the ability to mediate effects on cellular differentiation other than induction of apoptosis or $G_{1}$ cell cycle arrest. Two developmental phenotypes have been reported for $p 53$-deficient mice: (1) exencephaly in $\sim 17 \%$ of female embryos (Sah et al. 1995), and (2) persistence of certain blood vessels within the developing eye (Pan and Griep 1995). Notably, no alteration in the number of apoptotic cells was observed in exencephalic embryos to account for the first phenotype (Sah et al. 1995). Perhaps novel activities of p53 are responsible for such observations. Expression of wild-type human p53 under the control of the $\alpha$-crystallin promoter alters lens cell differentiation leading to microphthalmia in transgenic mice (Nakamura et al. 1995). This finding resembles the result presented here, as it suggests that p53 can affect cellular differentiation.

At least two types of transcriptional control by p53 could account for the altered differentiation of the ureteric bud. First, p53 might transcriptionally activate genes within cells of the ureteric bud, thereby interfering with proper differentiation. We have used Northern blotting to test for the induction of two p53 target genes, p21/WAF-1/Cip-1 (El-Diery et al. 1993; Harper et al. 1993) and thrombospondin-1 (Dameron et al. 1994) but have seen no differences between transgenic and nontransgenic kidneys (data not shown). Second, p53 may bind to transcriptional activators and prevent them from promoting the transcription of genes that do not contain p53 binding sites (Seto et al. 1992; Agoff et al. 1993; Mack et al. 1993). Though this has been demonstrated 
Godley et al.

Figure 8. Tests by immunofluorescence for renal differentiation markers. p53 transgenic kidneys were derived from heterozygous line B p53 transgenic mice. $(A-D)$ DB lectin immunofluorescence $(32 \times)$. $(A, B)$ El6.5 kidneys from nontransgenic control $(A)$ and $p 53$ transgenic $(B)$ mice. $(C, D) \mathrm{E} 18.5$ kidneys from nontransgenic control $(C)$ and p53 transgenic $(D)$ mice. $(E, F)$ Aquaporin 2 immunofluorescence of E18.5 kidneys $(32 \times)$ from nontransgenic control $|E|$ and $p 53$ transgenic $(F)$ mice. $(G, H)$ Lotus lectin immunofluorescence of $E 18.5$ kidneys $(32 \times)$ from nontransgenic control $(G)$ and $p 53$ transgenic $(H)$ mice. non-transgenic
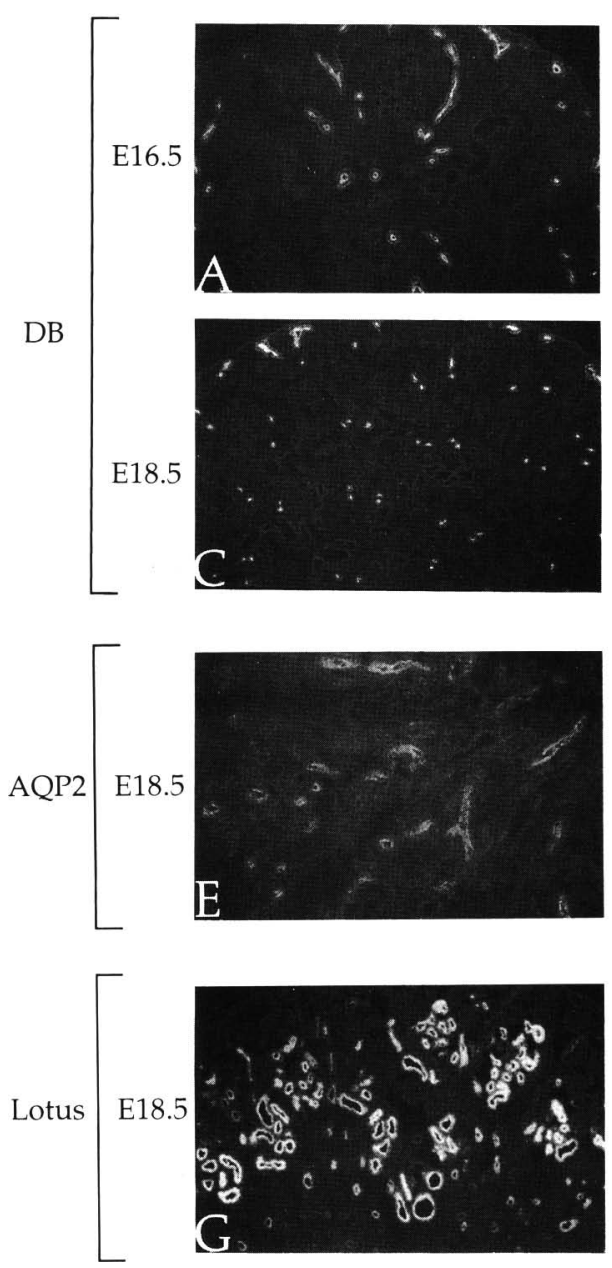

p53 transgenic
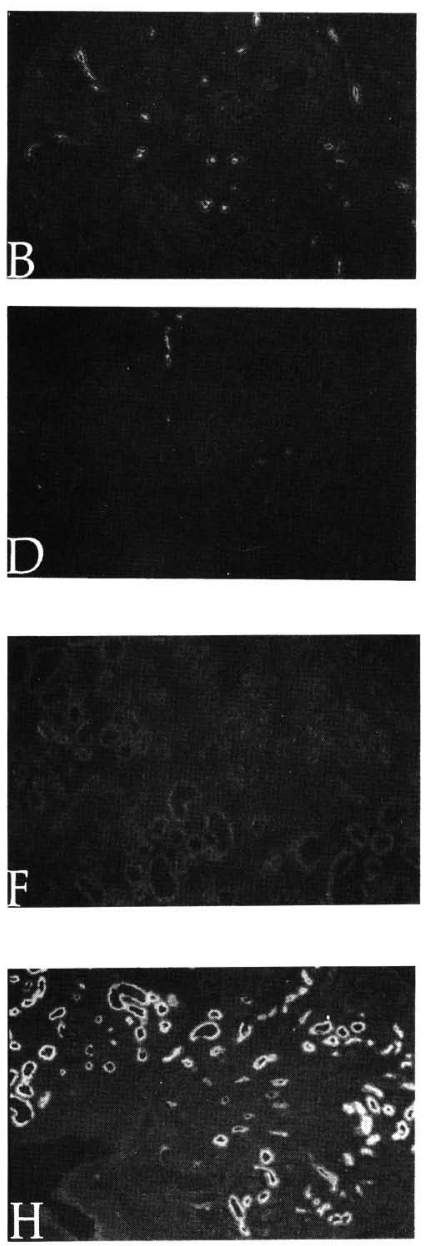

only in vitro, it is possible that $\mathrm{p} 53$ functions in this case by "squelching."

The abnormal expression of several proteins (c-ret, the protein that binds to DB lectin, and aquaporin 2) suggests a generalized defect in ureteric bud differentiation. Loss of these proteins or others could partially account for the altered function of the ureteric bud in our p53 transgenic mice. For example, the abnormal expression of c-ret in embryonic kidneys could contribute to the observed phenotype. Renal agenesis or severe dysgenesis results from c-ret deficiency, with decreased branching of the ureteric bud and absence of mature collecting ducts (Schuchardt et al. 1994). Because the sequence of c-ret suggests that it encodes a transmembrane tyrosine kinase receptor, c-ret may transduce a signal from the mesenchyme to the ureteric bud. In these $p 53$ transgenic mice, the ureteric bud may be unable to receive a signal from the metanephric mesenchyme during the period from E14.5 to E18.5, when c-ret expression is altered. This in turn could render the ureteric bud incapable of providing the necessary factors to the mesenchyme. Although we see defects in expression of c-ret from E14.5 to E18.5, some induction of the metanephric mesenchyme does occur during the first few days of this period. Thus, it is unlikely that altered c-ret expression completely explains the phenotype that we observe.

The proper expression of two markers of the proximal nephron (WT-1 and the protein that binds Lotus lectin) underscores the fact that the induction of metanephric mesenchyme that does take place is normal. The Wilms' tumor protein is known to bind to p53 and to inhibit its ability to induce apoptosis (Maheswaran et al. 1993; Maheswaran et al. 1995). However, this interaction is probably irrelevant here, as WT- 1 and the transgenic p53 are not expressed in the same cells. The defects noted within proximal nephron segments of p53 transgenic mice with end-stage disease probably result from abnormalities in more distal nephron segments.

The loss of uncommitted metanephric mesenchymal cells at E17.5 is most likely attributable to the ineffectual functioning of the ureteric bud at this time. Expression of the p53 transgene indirectly causes apoptosis of uninduced metanephric mesenchymal cells through its effects on the ureteric bud. It remains to be determined whether this apoptosis is dependent on endogenous p53 expression within mesenchymal cells (Schmid et al. 
1991). The death of a significant fraction of undifferentiated cells within the nephrogenic zone of developing kidneys causes p53 transgenic kidneys to be about half of their normal size.

The phenotype exhibited by these wild-type $p 53$ transgenic mice resembles a rare human disease-congenital oligomeganephronia. This condition is characterized by reduced renal mass, most commonly bilateral renal hypoplasia and occasionally unilateral renal agenesis, together with reduced nephron numbers and glomerular hypertrophy (Royer et al. 1962). Depending on severity of involvement, these patients develop proteinuria, focal segmental glomerulosclerosis, and ultimately renal failure (McGraw et al. 1984).

In addition to the p53 transgenic mice presented here, three other animal models for oligomeganephronia exist. oligosyndactyly (os) mice are born with a $50 \%$ reduction in nephron numbers and develop glomerulosclerosis $[\mathrm{He}$ et al. 1995). Mice deficient for cyclo-oxygenase 2 also develop segmental and global glomerulosclerosis in conjunction with reduced hypertrophied nephrons (Morham et al. 1995). Rats exposed in utero to gentamicin are born with a $20 \%$ reduction in nephron numbers and subsequently develop glomerular hypertrophy and increased numbers of sclerotic glomeruli (Gilbert et al. 1991). Multiple inducers of oligomeganephronia in animals, then, suggest that the human disease may have multiple causes, either inherited through gene mutations or acquired through environmental insults.

Limited expression of wild-type $p 53$, as presented here and by Nakamura et al. (1995), demonstrate the ability of p53 to affect cellular differentiation. Such transgenic systems may be viable because of the restricted range of $p 53$ expression. $m d m-2$ deficient mice contain unopposed p53 and die at implantation (Jones et al. 1995; Montes de Oca Luna et al. 1995). This lethality is rescued completely when mice also lack p53, suggesting that it is the action of p53 throughout the embryo that is incompatible with life. Because mice lacking an intact p53 gene usually proceed through embryogenesis without overt abnormalities (Donehower et al. 1992), mice appear to be more vulnerable to overexpression of $p 53$ than to $p 53$ deficiency.

\section{Materials and methods}

Construction of p53 transgenic fragments

The plasmids (pwtTG and pmutTG) containing the p53 transgenic fragments were constructed in three parts: insertion of intron 4 in p53 cDNA, placement of the MMTV LTR, and insertion of the SV40 polyadenylation site. Murine $p 53$ cDNA in pBS KS + | was partially digested with $N$ coI to obtain the fragment generated by cuts at positions 259 and 467 vithin the $p 53$ cDNA. pMSVp53G(18) from M. Oren (Weizmann Institute of Science, Rehovot, Israel) contains a murine p53 genomic clone and was cut with $\mathrm{NcoI}$ to isolate the fragment containing intron 4. The genomic $p 53$ fragment containing intron 4 was ligated to the NcoI fragment isolated from the $p 53$ cDNA to produce the plasmid called pmutp53.

The Ncol fragment obtained from the genomic clone contains a point mutation (GTG) at codon 135 (point mutation is given in bold). We performed site-directed mutagenesis on pmutp53 to produce plasmid pwtp53. In pwtp53, the mutant $T$ base pair within codon 135 was replaced by $\mathrm{C}$, so that this codon encodes Ala, the wild-type amino acid at that position. Site-directed mutagenesis was performed with the following mutagenesis primer: 5'-GCCAGCTGGCGAAGACGTGCCC-3'.

The MMTV LTR was released from pM5.3-12/Tsukamoto et al. 1988) by digestion with $B a m H I$ and purified. pBS containing p53 cDNA/intron 4 was cut with BamHI and ligated to the MMTV LTR. The SV40 polyadenylation site was amplified by PCR using the following two primers: 5 '-CGATAAGCTTTTTACTT-3' and 5'-CGTCGACGGATCCAGACATGATAA-3' so that a Sall site was added to the $3^{\prime}$ end of the fragment. Finally, the plasmid containing the MMTV LTR/p53 cDNA/ intron 4 was cut with HindIII and Sall and ligated with the SV40 polyadenylation site. In this orientation, the SV40 early polyadenylation signal is used. The p53 cDNA, the first $100 \mathrm{bp}$ of intron 4, the SV40 polyadenylation signal, and the $3^{\prime}$ end of the MMTV LTR were sequenced prior to injection of the fragment to confirm the integrity of the p53 sequence and the proper orientation of each fragment (Sequenase Kit, U.S. Biochemical). Both pmutp53 and pwtp53 were used in these ligations to produce two transgene-containing plasmids, one encoding wildtype $p 53$ (pwtTG) and one encoding the mutant Val 135 allele (pmutTG).

\section{Generation and maintenance of p53 transgenic mice}

Plasmids pwtTG and pmutTG were purified twice by $\mathrm{CsCl}$ banding, and the p53-containing fragment was released by digestion with SpeI and SalI and diluted to a final concentration of $3 \mathrm{ng} / \mathrm{ml}$. Each fragment was microinjected separately into the pronuclei of $\mathrm{FVB} / \mathrm{N}$ one-cell embryos using standard techniques (Hogan et al. 1986). Transgenic progeny were identified by Southern blotting of tail genomic DNA digested with BamHI and probed with the 325-bp XhoI-ApaLI fragment from the $p 53$ cDNA. Hybridizing digestion products represent the p53 pseudogene at $10 \mathrm{~kb}$, the endogenous $p 53$ gene at $6.4 \mathrm{~kb}$, and the p53 transgene at $2.19 \mathrm{~kb}$. Each founder animal was mated to an FVB/N animal of the opposite sex to establish individual lines.

Transgenic animals were identified either by the Southern blotting protocol described above or by PCR. To identify transgenic animals by PCR, $1 \mathrm{ml}$ of genomic tail DNA was used per $50-\mathrm{ml}$ reaction containing $2 \mathrm{ml}$ with $10 \mathrm{mM}$ of each $\mathrm{dNTP}, 5 \mathrm{ml}$ of $10 \times$ PCR buffer with gelatin, $15 \mathrm{mM} \mathrm{MgCl}_{2}, 2 \mathrm{ml}$ of $25 \mathrm{~mm}$ $\mathrm{MgCl}_{2}, 0.5 \mathrm{ml}$ of Taq polymerase, $0.5 \mathrm{ml}$ each of the following p53 oligonucleotides at $90 \mathrm{pmoles} / \mathrm{ml}: 5^{\prime}$-CCTCCCCTCAATAAGCTATTCTGC- $3^{\prime}$ and 5'-GGTGTGGGAGGTTTTTTAAAGCAAGTA- $3^{\prime}$, and $1 \mathrm{~mL}$ each of the following $\beta_{2}$ microglobulin primers at 90 pmoles $/ \mathrm{ml}$ : 5'-GCTATCCAGAAGAAACCCCTCAAATCC-3' and 5'-CATGTCTCGATCCCAGTAGACGGTC-3'. Cycling parameters of $94^{\circ} \mathrm{C}$ for $5 \mathrm{~min}$; $94^{\circ} \mathrm{C}$ for $45 \mathrm{sec}, 50^{\circ} \mathrm{C}$ for $1 \mathrm{~min}, 72^{\circ} \mathrm{C}$ for $2 \mathrm{~min} \times 30$ cycles; $72^{\circ} \mathrm{C}$ for $10 \mathrm{~min}$, and $4^{\circ} \mathrm{C}$ hold yielded a p53 transgene-specific PCR product of $\sim 800 \mathrm{bp}$ and a positive control product of about $300 \mathrm{bp}$.

To generate mice homozygous for a particular transgene, mice heterozygous for that transgene were mated. Progeny were screened by Southern blotting, with quantitation of transgene copy number calculated using a PhosPhorImager (Molecular Dynamics, Inc.).

To distinguish wild-type $p 53$ transgenic mice from those that contained the Val 135 allele, allele-specific oligonucleotide hybridization was used as described in (Hussussian et al. 1994). The oligonucleotide used to identify the wild-type $p 53$ allele 
was $5^{\prime}$-CCAGCTGGCGAAGACGT-3', and that used to identify the Val 135 allele was 5'-CCAGCTGGTGAAGACGT-3'.

\section{Northern blotting}

Total RNA was extracted from either fresh tissues or those frozen at $-80^{\circ} \mathrm{C}$ with RNAzol B Reagent (Tel-Test, Inc.) according to the manufacturer's instructions. Poly $(\mathrm{A})^{+}$RNA was isolated from total RNA by adsorbing the RNA to oligo(dT)-Sepharose (Collaborative Research, Inc.), washing, eluting with $\mathrm{H}_{2} \mathrm{O}$, and precipitating overnight at $-20^{\circ} \mathrm{C}$. One microgram of poly $(\mathrm{A})^{+}$RNA was electrophoresed through a $1 \%$ agarose formaldehyde gel and transferred to Hybond $\mathrm{N}$ (Amersham) in $20 \times$ SSC. Hybridizations were performed using the following probes

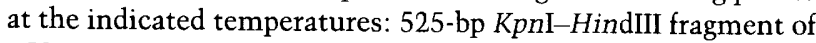
p53 cDNA at $65^{\circ} \mathrm{C} ; p 21 \mathrm{cDNA}$ at $65^{\circ} \mathrm{C}$.

\section{Preparation of histological sections}

Tissues were fixed for up to 3 days in $10 \%$ neutral buffered formalin and processed for either paraffin embedding or glycol methacrylate plastic embedding. Sections of the indicated thicknesses were stained with hematoxylin and eosin $(6 \mu \mathrm{m})$, periodic acid-Schiff (PAS) $(4 \mu \mathrm{m})$, or Masson's trichrome $(6 \mu \mathrm{m})$. For frozen sections, tissues were fixed in freshly prepared $4 \%$ paraformaldehyde $/ 1 \times$ PBS, bathed in $30 \%$ sucrose $/ 1 \times$ PBS for 6 hr, and embedded in O.C.T. Compound (Miles, Inc.). Frozen sections $(8 \mathrm{~mm})$ were cut and used as indicated. For electron microscopy, kidney tissue was fixed in $2 \%$ glutaraldehyde in 0.1 $M$ cacodylate buffer and embedded in Epon 812 resin (E.F. Fullan, Inc.). Semithin $(0.5-\mathrm{mm})$ sections were used for toluidine blue staining, and thin sections $(90 \mathrm{~nm})$ were prepared for examination by electron microscopy.

\section{Glomerular counts and morphometry}

Glomeruli were counted essentially as described previously (MacKay et al. 1987). Histomorphometry was performed on 2 $\mu \mathrm{m}$ PAS-stained glycol methacrylate sections. The outline of the glomerular tuft was traced using a Leica microscope equipped with a digitizing tablet, and the area of each tuft was calculated. All glomeruli per kidney section (ranging from 60 to 150 glomeruli per kidney/ were measured. The mean glomerular volume, $V_{\mathrm{G}}$, was calculated from the equation $V_{\mathrm{G}}=(b / \mathrm{k})\left(A_{\mathrm{G}}\right.$ ${ }^{3 / 2}$, where $b=1.38$ is the shape coefficient for spheres, $k=1.1$ is a size distribution coefficient based on an estimate of the coefficient of variation of glomerular size $(25 \%)$, and $A_{\mathrm{G}}$ is the mean glomerular area (Weibel 1979).

\section{Clinical chemistry}

Mice were bled retro-orbitally using heparinized capillary tubes (Fisher) and collected into Microvette serum separator tubes (Sarstedt). Clotted blood was spun at $7000 \mathrm{rpm}$ for $5 \mathrm{~min}$, and serum collected. BUN was measured by urease hydrolysis (Ektachem DT, Kodak). Urinary protein was measured by the biuret reaction, and urinary creatinine was measured by the Jaffe method, in both cases using an Hitachi 717 analyzer (Boehringer Mannheim). Urinary proteins were analyzed on $10 \%$ polyacrylamide gels, stained with Coomassie blue.

\section{TUNEL assay}

The TUNEL procedure was performed as described by Lowe et al. (1994).

\section{BrdU labeling and immunocytochemistry}

Brd U (15 mg/ml) (Sigma) was freshly prepared in $\mathrm{H}_{2} \mathrm{O}$ and administered to mice by intraperitoneal injection at a concentration of $150 \mathrm{mg} / \mathrm{kg}$. Mice were sacrificed $2 \mathrm{hr}$ later, and tissues fixed in Bouins fixative (Sigma) at $4^{\circ} \mathrm{C}$, overnight. Tissues were rinsed with tap water for several changes and rinsed into $70 \%$ EtOH. Tissues were paraffin-embedded, and sections cut onto gelatin-coated slides as indicated. After paraffin wax was removed from slides by xylene, slides were rehydrated and treated with $3 \mathrm{M} \mathrm{HCl}$ for $15 \mathrm{~min}$ at $23^{\circ} \mathrm{C}$. Slides were rinsed $5 \times 3 \mathrm{~min}$, and endogenous peroxidases blocked by incubation in $3 \% \mathrm{H}_{2} \mathrm{O}_{2}$ in $70 \% \mathrm{EtOH}$ for $10 \mathrm{~min}$. Slides were preblocked in horse serum (Vectastain ABC Kit, Vector Laboratories) for $30 \mathrm{~min}$, and incubated with anti-BrdU antibody (Becton Dickinson) at a $1: 100$ dilution in $1 \times$ PBS for 30 min. Biotinylated secondary antibody and streptavidin/peroxidase conjugate were added sequentially to slides for 30 min each. DAB substrate reaction (DAB Kit, Vector Laboratories) was performed for $10 \mathrm{~min}$, and slides counterstained in methyl green, dehydrated, and mounted.

\section{In situ hybridizations}

In situ hybridizations were performed essentially as described in Christofori et al. (1994), with the following changes. Frozen sections were treated with $1 \mathrm{mg} / \mathrm{ml}$ of proteinase K. ${ }^{35} \mathrm{~S}$-Labeled sense and antisense probes were generated from a linearized subclone of the following genes using the indicated polymerases: SV40 polyadenylation site (sense, T7 polymerase; antisense, T3 polymerase); rat c-ret clone (sense, T7 polymerase; antisense, $\mathrm{T} 3$ polymerase); and human WT-1 clone (sense, T7 polymerase; antisense, T3 polymerase). Slides were left on NTB2 nuclear emulsion for indicated periods of time: SV40 polyadenylation signal for 2 days; c-ret and WT-1 for 4 days.

\section{Lectin and aquaporin 2 immunohistochemistry}

The DB lectin and the lotus lectin were used as markers of the ureteric bud/collecting tubule and proximal tubule, respectively. Frozen sections were brought to room temperature, fixed in acetone for $20 \mathrm{~min}$ at $4^{\circ} \mathrm{C}$, and immersed in PBS. Sections were incubated with FITC-conjugated lectins (Sigma) at a final concentration of 50 and $25 \mu \mathrm{g} / \mathrm{ml}$ for DB lectin and lotus lectin, respectively, for $60 \mathrm{~min}$ at $37^{\circ} \mathrm{C}$, followed by six washes with PBS over $1 \mathrm{hr}$. For aquaporin 2 immunofluorescence, sections were blocked with normal goat serum for $20 \mathrm{~min}$, incubated with aquaporin 2 antibody $(2 \mu \mathrm{g} / \mathrm{ml})$ or normal rabbit $\operatorname{IgG}(2$ $\mu \mathrm{g} / \mathrm{ml}$ ) as a control for $1 \mathrm{hr}$ at $23^{\circ} \mathrm{C}$, washed in PBS, and incubated in FITC-conjugated secondary antibody for $30 \mathrm{~min}$ at $37^{\circ} \mathrm{C}$. The slides were mounted in an aqueous mounting medium and photographed using a microscope equipped for epifluorescence with a narrow-band pass filter.

\section{Acknowledgments}

We thank the following people: Wendy Hively, for expert technical assistance; Dr. Gabriella Ryan, for guidance in kidney organ cultures; Violeta Bigornia, Nina Carter, Shelley Chu, Theresa Hernandez, Joe Isaac, and Annie Merriweather for assistance during portions of this work; Dr. Doug Hanahan, Paul Naik, and Dr. Valentina Factor, for advice in producing transgenic mice, in situ hybridizations, and BrdU labeling, respectively; Drs. Vladimir Pecenka, Moshe Oren, Susanna Lee, Alan Perantoni, and David Beach for providing clones; Dr. Mark Knepper for providing anti-aquaporin 2 antibody; Dr. Liliane Striker, for advice in determining glomerular numbers and vol- 
umes; Dr. Victor Ferrans and Dr. Zu-Xi Yu, for fluorescence microphotography; and to previous or current members of the Varmus laboratory for encouragement and advice, especially Paul Bates, Mario Chamorro, Xi He, Helen Kwan, Yvonne Mark, John Murphy, Sophie Roy, Pam Schwartzberg, and Ian Taylor. Support for early phases of this work was provided to H.E.V. by the National Cancer Institute (CA39832) and the Melanie Mann Bronfman Trust. H.E.V. was an American Cancer Society research professor.

The publication costs of this article were defrayed in part by payment of page charges. This article must therefore be hereby marked "advertisement" in accordance with 18 USC section 1734 solely to indicate this fact.

\section{References}

Agoff, S.N., J. Hou, D.I.H. Linzer, and B. Wu. 1993. Regulation of the human hsp70 promoter by p53. Science 259: 84-87.

Bard, J.B.L. 1992. The development of the mouse kidney-Embryogenesis writ small. Curr. Opin. Genet. Devel. 2: 589595.

Beenken, S.W., G. Karsenty, L. Raycroft, and G. Lozano. 1991. An intron binding protein is required for transformation ability of p53. Nucleic Acids Res. 19: 4747-4752.

Bergh, J., T. Norberg, S. Sjogren, A. Lindgren, and L. Holmberg. 1995. Complete sequencing of the $p 53$ gene provides prognostic information in breast cancer patients, particularly in relation to adjuvant systemic therapy and radiotherapy. $\mathrm{Na}$ ture Med. 1: 1029-1034.

Brenner, B.M., D.L. Garcia, and S. Anderson. 1988. Glomeruli and blood pressure. Am. J. Hypertens. 1: 335-347.

Christofori, G., P. Naik, and D. Hanahan. 1994. A second signal supplied by insulin-like growth factor II in oncogene-induced tumorigenesis. Nature 369: 414-418.

Clarke, A.R., C.A. Purdie, D.J. Harrison, R.G. Morris, C.C. Bird, M.L. Hooper, and A.H. Wyllie. 1993. Thymocyte apoptosis induced by p53-dependent and independent pathways. $\mathrm{Na}$ ture 352: 849-852.

Dameron, K.M., O.V. Volpert, M.A. Tainsky, and N. Bouck. 1994. Control of angiogenesis in fibroblasts by p53 regulation of thrombospondin-1. Science 265: 1582-1584.

Donehower, L.A., M. Harvey, B.L. Slagle, M.J. McArthur Jr., C.A. Montgomery, J.S. Butel, and A. Bradley. 1992. Mice deficient for p 53 are developmentally normal but susceptible to spontaneous tumors. Nature 356: 215-221.

Donehower, L.A., L.A. Godley, C. Marcelo Aldaz, R. Pyle, Y.-P. Shi, D. Pinkel, J. Gray, A. Bradley, D. Medina, and H.E. Varmus. 1995. Deficiency of p53 accelerates mammary tumorigenesis in Wnt-1 transgenic mice and promotes chromosomal instability. Genes \& Dev. 9: 882-895.

El-Diery, W.S., T. Tokino, V.E. Velculescu, D.B. Levy, R. Parsons, J.M. Trent, D. Lin, W.E. Mercer, K.W. Kinzler, and B. Vogelstein. 1993. WAF1, a potential mediator of p53 tumor suppression. Cell 75: 817-825.

Gilbert, T., M. Lelievre-Pegorier, and C. Merlet-Benichou. 1991. Long-term effects of mild oligonephronia induced in utero by gentamicin in the rat. Pediatr. Res. 30: 450-456.

Greenblatt, M.S., W.P. Bennett, M. Hollstein, and C.C. Harris. 1994. Mutations in the p53 tumor suppressor gene: Clues to cancer etiology and molecular pathogenesis. Cancer Res. 54: 4855-4878.

Harper, J.W., G.R. Adami, N. Wei, K. Keyomarsi, and S.J. Elledge. 1993. The p21 CDK-interacting protein Cipl is a potent inhibitor of Gl cyclin-dependent kinases. Cell 75: 805-816.
He, C., R.K. Zaulps, D.A. Henderson, G.E. Striker, and L.J. Striker. 1995. Molecular analysis of spontaneous glomerulosclerosis in Os $/+$ mice, a model with reduced nephron mass. Am. I. Physiol. 269: F266-F273.

Hogan, B., F. Costantini, and E. Lacy. 1986. In Manipulating the mouse embryo. Cold Spring Harbor Laboratory, Cold Spring Harbor, N.Y.

Hostetter, T.H., J.L. Olson, H.G. Rennke, M.A. Venkalachalam, and B.M. Brenner. 1981. Hyperfiltration in remnant nephrons: a potentially adverse response to renal ablation. Am. J. Physiol. 79: F85-F93.

Howie, A.J., T. Kizaki, M. Beaman, C.M. Morland, R.J. Birtwistle, D. Adu, J. Michael, A.J. Williams, J. Walls, M. Matsuyama, and F. Shimizu. 1989. Different types of segmental sclerosing glomerular lesions in six experimental models of proteinuria. J. Pathol. 157: 141-151.

Hussussian, C.J., J.P. Struewing, A.M. Goldstein, P.A.T. Higgins, D.S. Ally, M.D. Sheahan, W.H. Clark, M.A. Tucker, and N.C. Dracopoli. 1994. Germline p16 mutations in familial melanoma. Nature Genet. 8: 15-21.

Jacks, T., L. Remington, B.O. Williams, E.M. Schmitt, S. Halachmi, R.T. Bronson, and R.A. Weinberg. 1994. Tumor spectrum analysis in p53-mutant mice. Curr. Biol. 4: 1-7.

Jayaraman, L. and C. Prives. 1995. Activation of p53 sequencespecific DNA binding by short single strands of DNA requires the p53 C-terminus. Cell 81: 1021-1029.

Jones, S.N., A.E. Roe, L.A. Donehower, and A. Bradley. 1995. Rescue of embryonic lethality in Mdm2-deficient mice by absence of p53. Nature 378: 206-208.

Kastan, M.B., O. Onyekwere, D. Sidransky, B. Vogelstein, and R.W. Craig. 1991. Participation of p53 protein in the cellular response to DNA damage. Cancer Res. 51: 6304-6311.

Kreidberg, J.A., H. Sariola, J.M. Loring, M. Maeda, J. Pelletier, D. Housman, and R. Jaenisch. 1993. WT-1 is required for early kidney development. Cell 74: 679-691.

Kuerbitz, S.J., B.S. Plunkett, W.V. Walsh, and M.B. Kastan. 1992. Wild-type p53 is a cell cycle checkpoint determinant following irradiation. Proc. Nat1. Acad. Sci. 89: 7491-7495.

Lee, S., B. Elenbaas, A. Levine, and J. Griffith. 1995. p53 and its $14 \mathrm{kDa}$ C-terminal domain recognize primary DNA damage in the form of insertion/deletion mismatches. Cell 81: 1013-1020.

Lowe, S.W., H.E. Ruley, T. Jacks, and D.E. Housman. 1993a. p53-dependent apoptosis modulates the cytotoxicity of anticancer agents. Cell 74: 957-967.

Lowe, S.W., E.M. Schmitt, S.W. Smith, B.A. Osborne, and T. Jacks. 1993b. p53 is required for radiation-induced apoptosis in mouse thymocytes. Nature 362: 847-849.

Lowe, S.W., S. Bodis, A. McClatchey, L. Remington, H.E. Ruley, D.E. Fisher, D.E. Housman, and T. Jacks. 1994. p53 status and the efficacy of cancer therapy in vivo. Science 266: $807-$ 810.

Mack, D.H., J. Vartikar, J.M. Pipas, and L.A. Laimins. 1993. Specific repression of TATA-mediated but not initiator-mediated transcription by wild-type p53. Nature 363: 281-283.

MacKay, K., L.J. Striker, C.A. Pinkert, R.L. Brinster, and G.E. Striker. 1987. Glomerulosclerosis and renal cysts in mice transgenic for the early region of SV40. Kidney Int. 32: 827837.

Maheswaran, S., S. Park, A. Bernard, J. Morris, F. Rauscher III, D. Hill, and D. Haber. 1993. Physical and functional interaction between WT1 and 533 proteins. Proc Natl. Acad. Sci. 90: 5100-5104.

Maheswaran, S., C. Englert, P. Bennett, G. Heinrich, and D.A. Haber. 1995. The WT1 gene product stabilizes p53 and inhibits p53-mediated apoptosis. Genes \& Dev. 9: 2143-2156. 
McGraw, M., S. Poucell, J. Sweet, and R. Baumal. 1984. The significance of focal segmental glomerulosclerosis in oligomeganephronia. Int. J. Pediatr. Nephrol. 5: 67-72.

Michalovitz, D., O. Halevy, and M. Oren. 1990. Conditional inhibition of transformation and of cell proliferation by a temperature-sensitive mutant of p53. Cell 62: 671-680.

Milner, J. and E.A. Medcalf. 1990. Temperature-dependent switching between "wild-type" and "mutant" forms of p53Val135. J. Mol. Biol. 216: 481-484.

Montes de Oca Luna, R., D.S. Wagner, and G. Lozano. 1995. Rescue of early embryonic lethality in mdm2-deficient mice by deletion of $p 53$. Nature 378: 203-206.

Morham, S.G., R. Langenbach, C.D. Loftin, H.F. Tiano, N. Vouloumanos, J.C. Jennette, J.F. Mahler, K.D. Kluckman, A. Ledford, C.A. Lee, and O. Smithies. 1995. Prostaglandin synthase 2 gene disruption causes severe renal pathology in the mouse. Cell 83: 473-482.

Nakamura, T., J.G. Pichel, L. Williams-Simons, and H. Westphal. 1995. An apoptotic defect in lens differentiation caused by human 553 is rescued by a mutant allele. Proc. Natl. Acad. Sci. 92: 6142-6146.

Pachnis, V., B. Mankoo, and F. Costantini. 1993. Expression of c-ret proto-oncogene during mouse embryogenesis. Development 119: 1005-1017.

Pan, H. and A.E. Griep. 1995. Temporally distinct patterns of p53-dependent and p53-independent apoptosis during mouse lens development. Genes \& Dev. 9: 2157-2169.

Pritchard-Jones, K., S. Fleming, D. Davidson, W. Bickmore, D. Porteous, C. Gosden, J. Bard, A. Buckler, J. Pelletier, D. Housman, V. van Heyningen, and N. Hastie. 1990. The candidate Wilms' tumour gene is involved in genitourinary development. Nature 346: 194-197.

Purdie, C.A., D.J. Harrison, A. Peter, L. Dobbie, S. White, S.E.M. Howie, D.M. Salter, C.C. Bird, A.H. Wyllie, M.L. Hooper, and A.R. Clarke. 1994. Tumour incidence, spectrum, and ploidy in mice with a large deletion in the p53 gene. Oncogene 9: 603-609.

Reed, M., B. Woelker, P. Wang, Y. Wang, M.E. Anderson, and P. Tegtmeyer. 1995. The C-terminal domain of p53 recognizes DNA damaged by ionizing radiation. Proc. Natl. Acad. Sci. 92: 9455-9459.

Royer, P., R. Habib, H. Mathieu, and V. Courtecuisse. 1962. L'hypoplasie rénal bilatèrale congénitale avec réduction du nombe et hypertrophie des néphrons chez l'enfant. Ann. Pe diatr. 9: 133-146.

Sabolic, I., T. Katsura, J.-M. Verbavatz, and D. Brown. 1995. The AQP2 water channel: Effect of vasopressin treatment, microtubule disruption, and distribution in neonatal rats. $I$. Membrane Biol. 143: 165-175.

Sah, V.P., L.D. Attardi, G.J. Mulligan, B.O. Williams, R.T. Bronson, and T. Jacks. 1995. A subset of p53-deficient embryos exhibit exencephaly. Nature Genet. 10: 175-180.

Schmid, P., A. Lorenz, H. Hameister, and M. Montenarh. 1991. Expression of p53 during mouse embryogenesis. Development 113: 857-865.

Schuchardt, A., V. D'Agati, L. Larsson-Blomberg, F. Costantini, and V. Pachnis. 1994. Defects in the kidney and enteric nervous system of mice lacking the tyrosine kinase receptor Ret. Nature 367: 380-383.

Seto, E., A. Usheva, G.P. Zambetti, J. Momand, N. Horikoshi, R. Weinmann, A.J. Levine, and T. Shenk. 1992. Wild-type p53 binds to the TATA-binding protein and represses transcription. Proc. Natl. Acad. Sci. 89: 12028-12032.

Thut, C.J., J.-L. Chen, R. Klemm, and R. Tjian. 1995. p53 transcriptional activation mediated by coactivators TAFII40 and TAFII60. Science 267: 100-104.
Tsukamoto, A.S., R. Grosschedl, R.C. Guman, T. Parslow, and H.E. Varmus. 1988. Expression of the int-1 gene in transgenic mice is associated with mammary gland hyperplasia and adenocarcinomas in male and female mice. Cell 55: 619-625.

Weibel, E.R. 1979. Stereologic methods. Academic Press, London, UK.

Yonish-Rouach, E., D. Resnitzky, J. Lotem, L. Sachs, A. Kimchi, and M. Oren. 1991. Wild-type p53 induces apoptosis of myeloid leukemic cells that is inhibited by interleukin-6. $\mathrm{Na}$ ture 352: 345-347. 


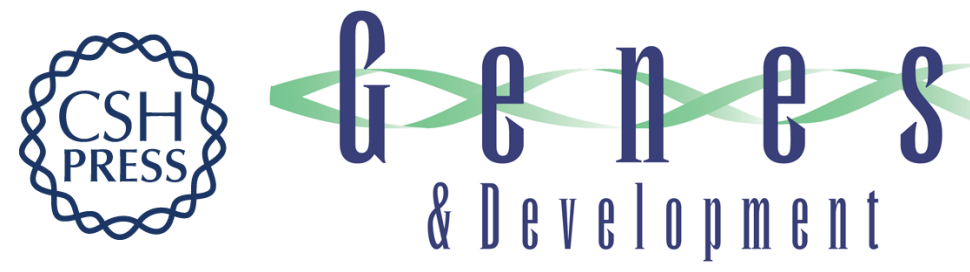

\section{Wild-type p53 transgenic mice exhibit altered differentiation of the ureteric bud and possess small kidneys.}

L A Godley, J B Kopp, M Eckhaus, et al.

Genes Dev. 1996, 10:

Access the most recent version at doi:10.1101/gad.10.7.836

References

This article cites 52 articles, 16 of which can be accessed free at:

http://genesdev.cshlp.org/content/10/7/836.full.html\#ref-list-1

License

Email Alerting

Receive free email alerts when new articles cite this article - sign up in the box at the top

Service right corner of the article or click here.

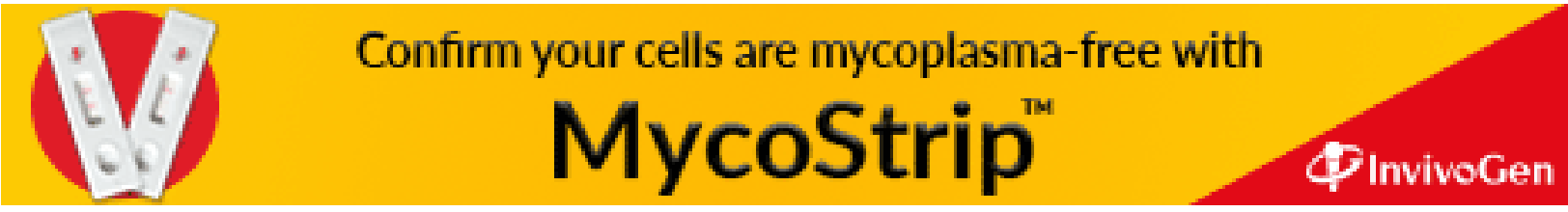

